\title{
Immune Checkpoints in Viral Infections
}

\author{
Huiming Cai 1,2, Ge Liu ${ }^{1,2}$, Jianfeng Zhong ${ }^{1,2}$, Kai Zheng ${ }^{1,2} \mathbb{D}$, Haitao Xiao ${ }^{1,2}$, Chenyang Li ${ }^{1,2}$, \\ Xun Song ${ }^{1,2}$, Ying $\mathrm{Li}^{1,2}$, Chenshu $\mathrm{Xu}^{1,2}$, Haiqiang $\mathrm{Wu}^{1,2}$, Zhendan $\mathrm{He}^{1,2, *}$ and \\ Qinchang Zhu ${ }^{1,2, *}$ \\ 1 Guangdong Key Laboratory for Genome Stability \& Human Disease Prevention, School of Pharmaceutical \\ Sciences, Shenzhen University, Shenzhen 518060, China; 2014224055@email.szu.edu.cn (H.C.); \\ lggege@szu.edu.cn (G.L.); 2016224006@email.szu.edu.cn (J.Z.); zhengk@szu.edu.cn (K.Z.); \\ xhaitao@szu.edu.cn (H.X.); lcy@szu.edu.cn (C.L.); xsong@szu.edu.cn (X.S.); li.ying@szu.edu.cn (Y.L.); \\ cshuxu@szu.edu.cn (C.X.); wuhq@szu.edu.cn (H.W.) \\ 2 Shenzhen Key Laboratory of Novel Natural Health Care Products, Innovation Platform for Natural Small \\ Molecule Drugs, Engineering Laboratory of Shenzhen Natural Small Molecule Innovative Drugs, \\ Shenzhen University Health Science Center, Shenzhen 518060, China \\ * Correspondence: hezhendan@szu.edu.cn (Z.H.); zhuqc@szu.edu.cn (Q.Z.)
}

Received: 25 August 2020; Accepted: 17 September 2020; Published: 21 September 2020

\begin{abstract}
As evidence has mounted that virus-infected cells, such as cancer cells, negatively regulate the function of T-cells via immune checkpoints, it has become increasingly clear that viral infections similarly exploit immune checkpoints as an immune system escape mechanism. Although immune checkpoint therapy has been successfully used in cancer treatment, numerous studies have suggested that such therapy may also be highly relevant for treating viral infection, especially chronic viral infections. However, it has not yet been applied in this manner. Here, we reviewed recent findings regarding immune checkpoints in viral infections, including COVID-19, and discussed the role of immune checkpoints in different viral infections, as well as the potential for applying immune checkpoint blockades as antiviral therapy.
\end{abstract}

Keywords: immune checkpoint; virus; chronic infection; immunotherapy

\section{Introduction}

Viral infections, especially chronic viral infections, are still a major threat to global health. Currently, the world is facing the serious challenge of a viral pandemic (coronavirus 2019; COVID-19) caused by severe acute respiratory syndrome coronavirus 2 (SARS-CoV-2), which has infected over 28,000,000 people and resulted in nearly 930,000 deaths globally. Additionally, more than 325 million people worldwide are infected with chronic hepatitis B [1] and about 1.2 million people worldwide die each year from acquired immune deficiency syndrome (AIDS) and related diseases [2]. In chronic viral infections, the virus escapes elimination by the immune system and establishes a persistent infection by modulating or regulating the host immune response [3]. Many chronic viral infections result in T-cell exhaustion, which is the main source of host difficulty in eliminating such infections [3,4]. As a negative regulatory signal for the activation and proliferation of T-cells, the immune checkpoint pathway is involved in the immune escape of many viruses $[5,6]$.

Immune checkpoint molecules are negative regulatory receptors expressed on immune cells. Under normal physiological conditions, they function as a brake for the immune system, maintaining self-tolerance and preventing immunopathology in the body [7]. However, these molecules have also been shown to participate in the mechanism of immune escape by causing T-cell dysfunction in a variety of diseases, such as cancer and infection. The expression of immune checkpoint molecules on suppressor cells, such as regulatory T- (Treg) and regulatory B (Breg)-cells, could affect the function 
and cytokine secretion of these cells. Although the concept of immune checkpoints was first proposed in 2006 [8], research on the checkpoint receptors began much earlier. Allison discovered cytotoxic T-lymphocyte-associated protein 4 (CTLA-4) in 1995 and began studying the therapeutic effect of anti-CTLA-4 antibody on tumors [9,10], and Honjo discovered programmed death-1 (PD-1) in 1992 [11]. Since then, additional immune checkpoint molecules, such as T-cell immunoglobulin and mucin domain-containing-3 (TIM-3) and lymphocyte activation gene-3 (LAG-3), have been discovered [12,13]. To date, at least six immune checkpoints have been found to be involved in viral infections.

Conventional antiviral therapy is usually incapable of eliminating chronic infection [14]. However, recent advances in cancer immunotherapy may be applicable as antiviral therapy for chronic viral infections. Seven immune checkpoint inhibitors (ICIs) targeting CTLA-4, PD-1, or programmed death-ligand-1 (PD-L1) have been approved for the treatment of certain cancers and have shown positive therapeutic outcomes in patients $[15,16]$. Moreover, as a new approach for effective T-cell activation, combination therapy targeting multiple immune checkpoints or applied with other therapeutic modalities such as vaccines are currently being tested in clinical trials [17]. Here, we reviewed the recent findings regarding immune checkpoints in viral infection. We also discussed the role of immune checkpoints in different viral infections and the potential of applying immune checkpoint blockades as antiviral therapy.

\section{Immune Checkpoints and Their T-cell Inactivation Pathways}

The immune checkpoint coinhibitory network acts by inhibiting T-cell activation through various mechanisms and signaling pathways (Figure 1, Table 1).

PD-1 is preferentially expressed on the surface of activated T-cells and B-cells. Its expression has also been observed on the surface of other immunocyte subsets, such as natural killer (NK) cells, monocytes, and dendritic cells (DCs) [18,19]. The cytoplasmic tail of PD-1 has an immunoreceptor tyrosine-based inhibition motif (ITIM) and an immunoreceptor tyrosine-based switch motif (ITSM). When it binds to its ligand PD-L1/PD-L2, PD-1 translocates to T-cell receptor (TCR) microclusters and recruits $\mathrm{SH} 2$ domain-containing tyrosine phosphatase 2 (SHP2) by phosphorylating tyrosine residues in the ITSM [20]. Subsequently, the dephosphorylation of Zap-70 and LCK by SHP2 leads to inhibition of the Ras-MEK-MAPK pathway and interference with CD28 costimulatory signaling [21,22]. Additionally, SHP2 recruitment blocks the activation of phosphoinositide 3-kinase (PI3K) by completely binding to the phosphorylation kinases, then inhibits downstream Akt activation, which ultimately downregulates the activation of T-cells. A recent study suggested that the immune inhibitory function of PD-1 may occur via an SHP2-independent pathway [23]. PD-1 also can inactivate T-cells by promoting microcluster formation and degrading TCR on the surface of T-cells [22].

CTLA-4 is an important co-inhibitory receptor on T-cells that downregulates T-cell activation and induces tolerance [24]. It is transiently expressed following T-cell activation and blocks the costimulatory effect of constitutively expressed CD28 by competing with CD28 for CD80 binding [25]; it then inhibits Akt activation by recruiting PP2A [26,27]. Based on work in murine T-cells, CTLA-4 engagement results in T-cell suppression by limiting nuclear factor (NF)- $\mathrm{KB}$ and AP-1 transcriptional activity $[28,29]$. Recent research found that CTLA-4 expression induces high levels of the proapoptotic protein Bim in CD8 ${ }^{+}$T-cells and promotes Bim-dependent apoptosis in T-cells [30].

TIM-3 is selectively expressed on CD4 ${ }^{+}$T helper (Th) 1 or Th17 cells [31], CD8 ${ }^{+}$T cytotoxic 1 (Tc1) cells, and Treg cells, and this expression can lead to inhibition of the Th1 response and apoptosis of antigen-specific cells. Under normal circumstances, the molecular adaptor human leukocyte antigen B (HLA-B)-associated transcript 3 (Bat3), which binds to the intracellular tail of TIM-3, protects Th1 cells from TIM-3-mediated cell death or exhaustion. When galectin-9 (Gal-9) binds to TIM-3, Bat3 is released from TIM-3, allowing TIM-3 to bind to the SH3 domain-containing TCR-associated intracellular kinase LCK and then to mediate downregulatory signals that inhibit Th1 responses [32]. Some research has suggested that TIM-3 suppresses T-cell activation by suppressing the nuclear factor of activated T-cells (NFAT) dephosphorylation and AP-1 transcription [33,34]. 


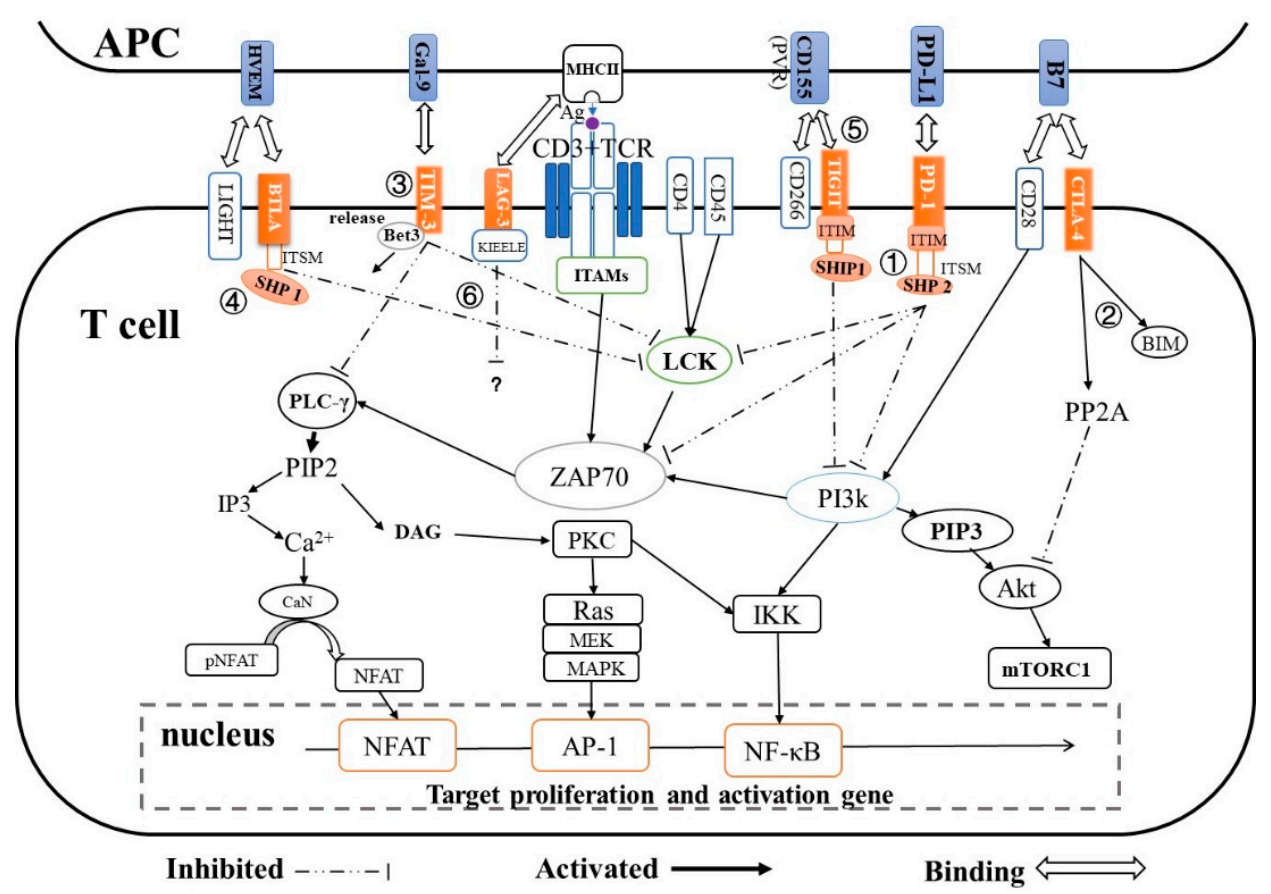

Figure 1. Mechanism of immune checkpoint-mediated T-cell inactivation. (1): PD-1/PD-L1 inhibits the PI3K/AKT pathway or ZAP70 phosphorylation by recruiting SHP2 phosphatase; (2): CTLA-4 competitively binds to the B7 ligand of CD28 and directly inhibits Akt by activating the phosphatase PP2A, and induces proapoptotic protein BIM; (3): TIM-3/Gal-9 releases Bat3, the molecule that binds to the intracellular tail of Tim-3, which allows Tim3 to bind to Lck or PLC- $\gamma$, leading to NF- $\mathrm{B}$ and NFAT inhibition; (4): BTLA/HVEM recruits SHP-1, leading to the inhibition of LCK-dependent T-cell activation; (5): TIGIT/CD155 directly inhibits T-cell activation and proliferation by countering the costimulatory function of CD226, and also inhibits PI3K and MAPK signaling pathway by recruiting SHIP-1; (6): Lag-3 downregulates T-cell activation through a still unclear mechanism. Abbreviations: ITAMs, immunoreceptor tyrosine-based activation motif 1 ; LCK, lymphocyte-specific protein tyrosine kinase; ZAP70, zeta chain of T-cell receptor associated protein kinase 70; PLC- $\gamma$, Phospholipase C- $\gamma$; PI3K, phosphatidylinositol 3-kinase; PIP3, phosphatidylinositol (3,4,5)-trisphosphate; PIP2, phosphatidyl inositol $(4,5)$ bisphosphate; IP3, inositol-1,4,5-trisphosphate; DAG, diacylglycerol; PKC, protein kinase C; CaN, Calcineurin; IKK, inhibitor of nuclear factor kappa-B kinase; Akt, protein kinase B (Also known as PKB or Rac); PP2A, Protein phosphatase 2 A; Ras/MEK/MAPK, Ras GTPase-protein/MAP kinase kinase/MAP kinase pathway; mTORC1, mammalian target of rapamycin complex 1; NFAT, nuclear factor of activated T-cells; pNFAT, phospho NFAT; AP-1, activator protein 1; NF-кB, nuclear factor-кB.

T-cell immunoglobulin and ITIM domain (TIGIT) is typically expressed on activated human T-cells, human NK cells, memory T-cells, and Treg cells. When TIGIT binds to CD155 (PVR) or CD112 (PVRL2 or Necl5) expressed on antigen-presenting cells (APCs), an inhibitory signal for T-cell activation is directly transmitted via the cytoplasmic tail of TIGIT [35]. The phosphorylated ITT-like motif in the TIGIT cytoplasmic tail binds the cytosolic adapter growth factor receptor bound protein 2 (Grb2) and then recruits SH2-containing inositol phosphatase-1 (SHIP-1), which further inhibits the PI3K and MAPK signaling pathway [31]. Additionally, TIGIT can also indirectly improve the negative regulation function of DCs and Treg cells [36,37].

LAG-3 is not expressed by naive T-cells, but its expression is induced upon T-cell activation. Compared with PD-1, LAG-3 displays a moderate immunosuppressive activity. LAG-3 can transmit inhibitory signals via the KIEELE motif in its cytoplasmic tail, the FXXL motif in its membrane-proximal region (PR), or its C-terminal EX repeat [38]. However, the molecular mechanism by which LAG-3 inhibits T-cell activation is still largely unknown. 
B and T lymphocyte attenuator (BTLA) is selectively expressed on Th1 cells and has been identified as an immune checkpoint receptor. Upon BTLA binding to herpesvirus entry mediator (HVEM), the BTLA cytoplasmic domains ITIM and ITSM bind to and activate the tyrosine phosphatases SHP-1 and SHP-2, which leads to the inhibition of lymphocyte-specific protein tyrosine kinase (LCK)-dependent T-cell activation [39,40]. Additionally, the third domain Grb-2-recognition motif in BTLA can recognize the Grb-2 protein, subsequently recruiting the PI3K protein subunit p85, stimulating the PI3K signaling pathway, and finally promoting cell proliferation and survival. Unlike other immune checkpoint regulators, BTLA can both positively and negatively co-stimulate T-cell regulation [41].

Table 1. Immune checkpoints involved in viral infections and their T-cell inactivation pathways.

\begin{tabular}{|c|c|c|c|c|c|}
\hline $\begin{array}{l}\text { Immune } \\
\text { Checkpoint }\end{array}$ & Super Family & Ligand & Expression & T-cell Inactivation Pathway & Ref. \\
\hline PD-1 & CD28 & PD-L1/L2 & $\begin{array}{l}\text { T-cells, B-cells, } \\
\text { natural killer } \\
\text { T-cells, DCs and } \\
\text { activated } \\
\text { monocytes }\end{array}$ & $\begin{array}{ll}\text { (1) } & \text { PD-1(ITSMs) } \rightarrow \text { SHP2 } \rightarrow \\
& \text { ZAP70/LCK } \rightarrow \\
& \text { Ras-MEK-MAPK } \rightarrow \text { AP1 } \\
\text { (2) } & \text { PD-1(ITSMs) } \rightarrow \text { SHP2 } \rightarrow \\
& \text { PI3K/AKT } \rightarrow \text { NFAT }\end{array}$ & [20-22] \\
\hline CTLA-4 & CD28 & $\begin{array}{c}\mathrm{B} 7 \\
(\mathrm{CD} 80 / \mathrm{CD} 86)\end{array}$ & Active T-cells & $\begin{array}{c}\text { CTLA- } 4 \rightarrow \text { PP2A } \rightarrow \text { Akt } \rightarrow \\
\text { mTORc1 } \rightarrow \text { regulates T-cell } \\
\text { proliferation and differentiation }\end{array}$ & [25-27] \\
\hline TIM-3 & TIM & Galcetin-9 & Th1, Tc1, Treg cells & $\begin{array}{ll}\text { (1) } & \text { TIM-3 } \rightarrow \text { release Bat } 3 \rightarrow \\
& \text { LCK } / \text { FYN } \rightarrow \text { ZAP70 } \rightarrow \\
& \text { Ras-MEK-MAPK } \rightarrow \text { AP1 } \\
\text { (2) } \quad \text { TIM- } 3 \rightarrow \text { release Bat3 } \rightarrow \\
\text { LCK } / \text { FYN } \rightarrow \text { ZAP70 } \rightarrow \\
\text { PLC- } \gamma \rightarrow \text { NFAT }\end{array}$ & [32] \\
\hline TIGIT & CD28 & CD155 on DCs & T-cells and NK cells & $\begin{aligned} \text { TIGIT } \rightarrow \text { SHIP1 } & \rightarrow \text { PI3K } \rightarrow \\
\text { AKT/PKC/IKK } & \rightarrow \text { NF-KB }\end{aligned}$ & {$[31,35]$} \\
\hline LAG-3 & Immunoglobulin & MHC class II & $\begin{array}{l}\text { Activated T-cells } \\
\text { Treg cells, B-cells, } \\
\text { DCs and NK cells }\end{array}$ & $\begin{array}{l}\text { LAG- KIEELE motif /FXXL motif/ } \\
\text { C terminus EX repeat } \rightarrow \text { unknown }\end{array}$ & [38] \\
\hline BTLA/CD160 & CD28 & HVEM & $\begin{array}{l}\text { T-cells and B-cells, } \\
\text { activated T-cells }\end{array}$ & $\begin{array}{ll}\text { (1) } & \text { BTLA(ITIM/ITSM) } \rightarrow \\
& \text { SHP- } 1 / 2 \rightarrow \text { LCK / FYN } \rightarrow \\
& \text { ZAP70 } \rightarrow \text { Ras-MEK-MAPK } \\
& \rightarrow \text { AP1 } \\
\text { (2) } & \text { BTLA(ITIM/ITSM) } \rightarrow \\
& \text { SHP- } 1 / 2 \rightarrow \text { LCK } / \text { FYN } \rightarrow \\
& \text { ZAP70 } \rightarrow \text { PLC- } \gamma \rightarrow \text { NFAT }\end{array}$ & {$[39,41]$} \\
\hline
\end{tabular}

\section{Immune Checkpoints in HIV}

Human immunodeficiency virus (HIV) infects mainly T-cells. HIV infection destroys the host immune system and makes the infected individual increasingly more vulnerable to a range of infections, cancers, and other diseases. Recent research has shown that immune checkpoints extensively participate in HIV infection via their role in inhibiting T-cell function; the two main ways in which they act are by causing T-cell exhaustion and helping to establish HIV-latency reservoirs [42,43].

\subsection{HIV-Specific T-cell Exhaustion Accompanies Immune Checkpoint Upregulation}

T-cell exhaustion, which is a deterioration of T-cell function caused by exposure to persistent stimulation with high levels of antigen, is widely observed in chronic viral infection. It is defined by poor effector function, sustained inhibitory receptor expression, and a transcriptional state distinct 
from that of functional effector or memory T-cells [44]. Immune checkpoints are recognized inhibitory regulators of T-cell function and they have been reported to cause T-cell exhaustion. Upregulated expression of immune checkpoint proteins is a hallmark of T-cell exhaustion and dysfunction. During HIV infection, HIV-specific T-cells display upregulated expression of multiple immune checkpoint proteins [45], functional exhaustion, and failure to control viral infection (Table 2).

Table 2. Summary of the roles of immune checkpoints in viral infections.

\begin{tabular}{|c|c|c|c|c|}
\hline Virus & Manifestations & $\begin{array}{l}\text { Checkpoints } \\
\text { Involved }\end{array}$ & Functions & Ref. \\
\hline \multirow{4}{*}{ HIV } & $\begin{array}{l}\text { Establishment of HIV latency } \\
\text { reservoirs }\end{array}$ & $\begin{array}{l}\text { PD-1, CTLA-4, } \\
\text { LAG-3, TIGIT }\end{array}$ & $\begin{array}{l}\text { Participate in HIV infection and } \\
\text { assist to virus escape from } \\
\text { immune clearance }\end{array}$ & {$[43,46-49]$} \\
\hline & $\mathrm{CD}^{+}$T-cell dysfunction & $\begin{array}{l}\text { PD-1, CTLA-4, } \\
\text { LAG-3, TIM-3 }\end{array}$ & $\begin{array}{l}\text { Cause many CD4 T-cells } \\
\text { dysfunction and loss }\end{array}$ & {$[46,50-53]$} \\
\hline & $\mathrm{CD}^{+}$T-cell exhaustion & $\begin{array}{l}\text { PD-1, TIM-3, } \\
\text { LAG-3, TIGIT }\end{array}$ & $\begin{array}{l}\text { Lead to CD8 }{ }^{+} \text {T-cell functional } \\
\text { impact such as decreased IL-2 } \\
\text { secretion and T-cell proliferation }\end{array}$ & $\begin{array}{l}{[42,46,54,} \\
55]\end{array}$ \\
\hline & Improved Treg proliferation & $\begin{array}{l}\text { TIM-3, CTLA-4, } \\
\text { PD-1 }\end{array}$ & $\begin{array}{c}\text { Decrease the HIV-specific } \\
\text { immune responses, contributing } \\
\text { to virus persistence }\end{array}$ & [56-59] \\
\hline \multirow{4}{*}{ HBV } & $\mathrm{CD}^{+}$T-cell exhaustion & $\begin{array}{l}\text { PD-1, CTLA-4, } \\
\text { Tim-3, TIGIT, } \\
\text { LAG-3 }\end{array}$ & $\begin{array}{l}\text { Lead to CD8 }{ }^{+} \text {T-cell functional } \\
\text { impact such as decreased IL-2 } \\
\text { secretion and T-cell proliferation }\end{array}$ & [60-63] \\
\hline & Upregulation on $\mathrm{CD}^{+}{ }^{+} \mathrm{T}$-cell & $\begin{array}{l}\text { PD-1, CTLA-4, } \\
\text { Tim-3 }\end{array}$ & \multirow{2}{*}{$\begin{array}{l}\text { Increase Treg and regulate } \\
\text { Th1/Th2 cytokine secretion }\end{array}$} & [64-67] \\
\hline & Altered cytokine secretion & See Table 4 & & See Table 4 \\
\hline & Limited liver injury & LAG-3 & $\begin{array}{l}\text { Suppress T-cell function and } \\
\text { mitigate liver injury }\end{array}$ & [68] \\
\hline \multirow{3}{*}{$\mathrm{HCV}$} & $\mathrm{CD}^{+}$T-cell exhaustion & $\begin{array}{l}\text { PD-1, TIGIT, Tim3, } \\
\text { CTLA-4 }\end{array}$ & $\begin{array}{c}\text { cause } \mathrm{CD} 8^{+} \text {T-cell functional } \\
\text { defect such as decreased IL-2 } \\
\text { secretion and T-cell proliferation }\end{array}$ & [69-72] \\
\hline & Up-regulation on $\mathrm{CD}^{+}{ }^{+} \mathrm{T}$-cell & CTLA-4, TIM-3 & \multirow{2}{*}{$\begin{array}{l}\text { Improve viral replication and } \\
\text { persistence }\end{array}$} & {$[67,73]$} \\
\hline & Altered cytokine secretion & See Table 4 & & See Table 4 \\
\hline \multirow[b]{2}{*}{ Influenza } & $\begin{array}{l}\text { Decrease in } \mathrm{CD}^{+} \mathrm{T} \text {-cell } \\
\text { response }\end{array}$ & PD-1, Tim-3 & $\begin{array}{l}\text { Reduce the number of } \\
\text { virus-specific } \mathrm{CD} 8^{+} \mathrm{T} \text {-cell and } \\
\text { cause T-cell dysfunction }\end{array}$ & \multirow{2}{*}{ [74-82] } \\
\hline & $\begin{array}{c}\text { Up-regulation on both CD4 }{ }^{+} \\
\text {and CD } 8^{+} \text {T-cells from patients } \\
\text { with influenza-associated } \\
\text { encephalopathy }\end{array}$ & CTLA-4 & $\begin{array}{l}\text { Involved in influenza } \\
\text { virus-associated encephalopathy }\end{array}$ & \\
\hline SARS-CoV-2 & $\begin{array}{l}\text { Up-regulation on T-cells and NK } \\
\text { cells from COVID-19 patients. } \\
\text { Patient deteriorated from } \\
\text { prodromal to symptomatic }\end{array}$ & PD-1, TIM-3 & $\begin{array}{l}\text { Mediate T-cell exhaustion and } \\
\text { T-cell lymphopenia }\end{array}$ & [83-85] \\
\hline \multirow{2}{*}{ HSV-1 } & $\mathrm{CD}^{+}$T-cell exhaustion & PD-1, LAG-3 & $\begin{array}{l}\text { Cause T-cell exhaustion and } \\
\text { assist viral latency infection }\end{array}$ & [86-88] \\
\hline & Reactivation of latency virus & $\begin{array}{l}\text { PD-1, CTLA-4, } \\
\text { TIM3 }\end{array}$ & $\begin{array}{l}\text { Mediate T-cell exhaustion and } \\
\text { make them lost the control of } \\
\text { spontaneous HSV-1 reactivation }\end{array}$ & [89] \\
\hline \multirow[t]{2}{*}{ EBV } & Up-regulated expression & $\begin{array}{l}\text { PD-1, CTLA-4, } \\
\text { TIM3, 2B4 }\end{array}$ & \multirow{2}{*}{$\begin{array}{l}\text { Provide T-cell dysfunction } \\
\text { status to increase EBV escape } \\
\text { and EBV latent infections }\end{array}$} & \multirow[t]{2}{*}{ [90-93] } \\
\hline & Immune escape & PD-1 & & \\
\hline Ebola virus & $\begin{array}{l}\text { Upregulation on both } \mathrm{CD}^{+} \text {and } \\
\text { CD8 } 8^{+} \text {T-cells; Associated with } \\
\text { high viremia and poor outcome }\end{array}$ & CTLA-4, PD-1 & Mediate immune suppression & [94] \\
\hline
\end{tabular}


The exhaustion of CD8 ${ }^{+}$T-cells in HIV-infected individuals has been found to accompany the upregulated expression of various immune checkpoint proteins such as PD-1, TIM-3, LAG-3, and TIGIT $[42,46,54,55,95]$. Blockade of the PD-1/PD-L1 pathway significantly reduces HIV or SIV viral load and reinvigorates exhausted $\mathrm{CD} 8^{+} \mathrm{T}$-cells in bone marrow-liver-thymus (BLT) humanized mice [96]. In addition, a blockade targeting TIM-3 and BTLA partially augmented the proliferation of HIV-specific CD8 ${ }^{+}$T-cells, whereas combined blockades of PD-1 and TIM-3 or BTLA enhanced the proliferation of $\mathrm{CD} 8^{+} \mathrm{T}$-cells and the production of cytokines such as tumor necrosis factor (TNF)- $\alpha$, interferon (IFN)- $\gamma$, and interleukin (IL)-13 [97].

As the HIV-infected target, $\mathrm{HIV}$-specific $\mathrm{CD}^{+}{ }^{+} \mathrm{T}$-cells are severely suppressed during infection. Most activated $\mathrm{CD} 4^{+}$T-cells die from HIV cytopathogenicity or immune-mediated cell death. Compared with healthy controls, the expression levels of PD-1, CTLA-4, TIM-3, LAG-3, and TIGIT on effector CD4 ${ }^{+}$ T-cells are elevated to varying degrees, accompanied by $\mathrm{CD}^{+} \mathrm{T}$-cell function impairment and disease progression [47,50-52,98-100]. For example, upregulation of PD-1 and CTLA-4 expression is associated with higher plasma viral loads and lower $\mathrm{CD}^{+}$T-cell counts. Enhancements in CTLA-4, TIM-3, LAG-3, and TIGIT expression in HIV-infected CD4 ${ }^{+}$T-cells are also associated with the integration of HIV-DNA in these cells $[46,50,51,53,101,102]$. Additionally, the upregulation of CTLA-4 in CD4 ${ }^{+}$ T-cells was reported to cause a high level of CCR5 expression on CD4 ${ }^{+} \mathrm{T}$-cells, thereby supporting a vigorous HIV-1 infection [48], which suggests that CTLA-4 upregulation by HIV infection could increase $\mathrm{CD}^{+}{ }^{+} \mathrm{T}$-cell susceptibility to HIV infection.

Treg cells are a subset of $\mathrm{CD} 4^{+} \mathrm{T}$-cells that express nuclear transcription factor fork head box P3 (Foxp3) and surface CD25. Under normal physiologic conditions, an increase in Treg cells protects tissues from damage due to excessive immune cell activation and proliferation [103]; however, it also plays a critical role in the immune suppressive reaction that is critical for chronic viral persistence [104,105]. Treg cells from HIV-1-infected patients express significantly higher levels of PD-1 [56,57], TIM-3 [106], CTLA-4 [107], and LAG-3 (Tr1) [58,59] compared with those from healthy individuals. Treg cells partly lose their ability to regulate T-cell function and proliferation during the chronic phase of HIV infection [108].

In summary, evidence suggests that the co-expression or single expression of immune checkpoint proteins is a key mechanism for the functional impairment of HIV-specific T-cells [109,110]. During acute HIV infection, progressive $\mathrm{CD} 4^{+} \mathrm{T}$-cell dysfunction alters cytokine secretion [111] and reduces HIV clearance. Persistent TCR stimulation and the inflammatory environment during HIV infection spawn $\mathrm{CD}^{+}$T-cell exhaustion, resulting in more T-cell apoptosis and decreased T-cell cytotoxic ability. Therefore, untreated individuals eventually develop uncontrolled viremia and chronic HIV infection [112].

\subsection{The Upregulation of Immune Checkpoint Proteins Helps to Establish a Latent HIV Reservoir}

The progressive loss of $\mathrm{CD}^{+}$T-cells during HIV infection follows two patterns: the amount of HIV-infected $\mathrm{CD}^{+}$T-cells decreases sharply during acute infection $[113,114]$ and the plasma $\mathrm{CD} 4^{+}$ T-cell population is gradually drained further during chronic infection $[115,116]$. Some HIV-infected T-cells will survive immune clearance and become long-lived resting memory $\mathrm{CD} 4^{+}$cells, which harbor the replication-competent HIV provirus $[117,118]$. These cells are known as the functional HIV reservoir, which is the main cause of HIV chronic infection. Some studies have shown that HIV-DNA is often found in resting memory $\mathrm{CD}^{+}{ }^{+} \mathrm{T}$-cells [117]. The main cell types acting as HIV reservoirs include central memory $\left(\mathrm{T}_{\mathrm{CM}}\right) \mathrm{CD} 4^{+} \mathrm{T}$-cells, transitional memory $\left(\mathrm{T}_{\mathrm{TM}}\right) \mathrm{CD} 4^{+} \mathrm{T}$-cells, and specific differentiation subtypes, such as effector-memory $\left(\mathrm{T}_{\mathrm{EM}}\right)$ cells and terminally differentiated effector (TEMRA) cells $[45,119]$.

Antiretroviral therapy (ART) can observably suppress viral replication, halt disease progression, and reduce viral loads in patients [120]. With such treatment, HIV infection can be manageable; however, if ART is stopped, the infection will rebound rapidly [121,122]. The post-integration latency of HIV is the biggest obstacle for treating HIV infection with ART because ART cannot eliminate 
non-replicating virus [123]. Until a new approach capable of eliminating the HIV reservoir is found, patients with HIV will require lifelong ART to ensure virus suppression.

Therapy targeting immune checkpoint proteins shows potential for eliminating HIV reservoirs. Multiple immune checkpoint receptors were found to be expressed on latent HIV-1 reservoir cells and associated with the amount of integrated HIV-DNA [102,124,125]. During ART, the CD4 ${ }^{+}$T-cells expressing PD-1, TIGIT, and LAG-3 alone or in combination were highly enriched for integrated viral genomes as compared with immune checkpoint receptor-negative $\mathrm{CD}^{+}$memory T-cells isolated from HIV-infected individuals [101]. The number of simultaneously co-expressed immune checkpoint receptors on $\mathrm{CD}^{+}{ }^{+} \mathrm{T}$-cells was closely related to the reservoir size and CD4 ${ }^{+} \mathrm{T}$-cell counts $[45,102,126]$. These findings suggest that immune checkpoints might help to establish latent HIV reservoirs.

Even after years of ART, PD-1 is preferentially expressed on the surface of persistently infected cells, including HIV-1 latent reservoir cells such as $\mathrm{T}_{\mathrm{CM}}, \mathrm{T}_{\mathrm{EM}}$, and follicular helper $\mathrm{T}$ (Tfh) cells $[49,126]$. Recently, Tfh cells were found to serve as the major hideout for HIV replication and production in HIV-infected individuals undergoing ART $[43,127,128]$. The increased PD-1 expression by CD4 ${ }^{+}$ T-cells is derived from the cell HIV-viral load. This expression is positively correlated with disease progression $[42,125]$ and involved in the reduction of immune system activation that leads to the long-term survival of HIV latent reservoir T-cells [42,129]. In addition, CTLA- $4^{+} \mathrm{PD}-1^{-}$memory CD $4^{+}$ T-cells have also been identified as HIV-DNA latency reservoir, and the major proportion of these cells were Treg cells [130,131].

In an in vitro HIV-latency model, a PD-L1/PD-1 blockade enhanced HIV-specific CD4 ${ }^{+}$T-cell proliferation and cytokine secretion [132]. Blocking PD-1 can potentiate viral reactivation from latency and reduce the size of HIV latency reservoirs $[126,133,134]$. One study found that blockade of a single immune checkpoint could retard but not eliminate the HIV latency reservoir because the exhausted T-cells could still express other immune checkpoint receptors. The combination of PD-1- and BTLA/TIM-3-specific antibodies showed enhanced therapeutic potential to augment T-cell responses [97]. Currently, several clinical trials aimed at determining the safety and efficacy of using ICIs as anti-HIV therapy are ongoing (Table 3 ).

Table 3. Clinical trials on immune checkpoint inhibitors targeting viral infection.

\begin{tabular}{|c|c|c|c|c|c|}
\hline Infection & Target & NCT ID & Research Title/Objective & Drug & Status \\
\hline \multirow{4}{*}{ HIV } & PD-1 & NCT03239899 & $\begin{array}{l}\text { PD-1 Inhibition to Determine CNS } \\
\text { Reservoir of HIV-Infection }\end{array}$ & Pembrolizumab & Phase I \\
\hline & PD-1 & NCT03787095 & $\begin{array}{l}\text { Safety and Immunotherapeutic } \\
\text { Activity of an Anti-PD-1 Antibody } \\
\text { (Cemiplimab) in HIV-1-infected } \\
\text { Participants on Suppressive cART }\end{array}$ & Cemiplimab & Phase I \\
\hline & IMC & NCT03354936 & $\begin{array}{l}\text { Assess the safety of the use of } \\
\text { immune checkpoint inhibitors in HIV } \\
\text { infected patients }\end{array}$ & $\begin{array}{l}\text { Nivolumab, } \\
\text { Pembrolizumab }\end{array}$ & Recruiting \\
\hline & PD-1 & NCT03367754 & $\begin{array}{l}\text { A Single Dose of Pembrolizumab in } \\
\text { HIV-Infected People }\end{array}$ & Pembrolizumab & Phase I \\
\hline HBV & PD-L1 & NCT03899428 & $\begin{array}{l}\text { Immune Checkpoint Therapy vs } \\
\text { Target Therapy in Reducing Serum } \\
\text { HBsAg Levels in Patients with } \\
\text { HBsAg+ Advanced Stage HCC }\end{array}$ & Durvalumab & Phase II \\
\hline $\mathrm{HCV}$ & PD-1 & NCT00703469 & $\begin{array}{l}\text { A Study of MDX-1106 to Treat } \\
\text { Patients with Hepatitis C Infection } \\
\text { (MDX1106-02) }\end{array}$ & $\begin{array}{l}\text { MDX-1106 } \\
(\text { PD-1 ab) }\end{array}$ & Phase I \\
\hline
\end{tabular}


Table 3. Cont

\begin{tabular}{|c|c|c|c|c|c|}
\hline Infection & Target & NCT ID & Research Title/Objective & Drug & Status \\
\hline \multirow[t]{2}{*}{ Influenza } & PD-1 & NCT03061955 & $\begin{array}{c}\text { Safety and Efficacy of Concurrent } \\
\text { Administration of Influenza Vaccine } \\
\text { in Patients Undergoing Anti-PD-1 } \\
\text { Immunotherapy (Nivolumab, } \\
\text { Pembrolizumab) }\end{array}$ & $\begin{array}{l}\text { Nivolumab, } \\
\text { Pembrolizumab }\end{array}$ & Completed \\
\hline & PD-1/CTLA-4 & NCT03590808 & $\begin{array}{l}\text { Influenza Vaccination in Patients } \\
\text { Receiving Immune Checkpoint } \\
\text { Inhibitor }\end{array}$ & $\begin{array}{l}\text { Pembrolizumab, } \\
\text { Nivolumab, } \\
\text { Ipilimumab }\end{array}$ & Completed \\
\hline $\mathrm{HPV}$ & CTLA-4 & NCT01693783 & $\begin{array}{c}\text { Ipilimumab in Treating Patients with } \\
\text { Metastatic or Recurrent Human } \\
\text { Papilloma Virus-Related Cervical } \\
\text { Cancer }\end{array}$ & Ipilimumab & Phase II \\
\hline \multirow[b]{2}{*}{ EBV } & PD-1 & NCT03755440 & $\begin{array}{l}\text { PD-1 Antibody in EBV Positive } \\
\text { Metastatic Gastric Cancer Patients }\end{array}$ & $\begin{array}{l}\text { SHR-1210 } \\
\text { (PD-1 ab) }\end{array}$ & Phase II \\
\hline & PD-1 & NCT02488759 & $\begin{array}{l}\text { An Investigational Immuno-Therapy } \\
\text { Study to Investigate the Safety and } \\
\text { Effectiveness of Nivolumab, } \\
\text { and Nivolumab Combination } \\
\text { Therapy in Virus-associated Tumors } \\
\text { (CheckMate358) }\end{array}$ & Nivolumab & Phase I \\
\hline
\end{tabular}

\section{Immune Checkpoints in Hepatitis Virus}

Chronic infection caused by hepatitis B virus (HBV) or hepatitis C virus (HCV) is the main cause of liver cancer. Around $15 \%-40 \%$ of HBV-infected individuals are predisposed to cirrhosis or hepatocellular carcinoma (HCC) [135]. In Japan, HCV infection is the major risk factor for HCC (80\%-90\%) [136]. Three-quarters of HCV infections develop into chronic hepatitis. Fortunately, highly effective direct acting antivirals (DAA) targeting NS3 protease, NS5A polymerase, or NS5B polymerase can cure over $95 \%$ of HCV-infected individuals [137]. HBV is a small, enveloped, DNA virus. During HBV infection of hepatocytes, the relaxed circular DNA genome (rcDNA) of HBV is transported into the nucleus and converted into covalently closed circular DNA (cccDNA) to serve as a viral persistence reservoir [138], which is refractory to current antiviral therapies [139]. Life-long nucleoside/nucleotide analogue (NA) therapy can achieve long-term suppression of viral replication, but it cannot eliminate cccDNA. Consequently, the withdrawal of NA therapy poses the risk of viral rebound [140].

\subsection{Hepatitis Virus Infection Upregulates Immune Checkpoint Proteins on T-cells}

In acute HBV infection, immune checkpoints are upregulated in T-cells, but they mainly limit intrahepatic inflammation [141]. However, immune suppression due to immune checkpoints was also found to enhance viral persistence and lead to chronic infection. The expression levels of PD-1, TIM-3, TIGIT, LAG-3, and CTLA-4 have been observed to increase on peripheral HBV-specific CD8 ${ }^{+}$ T-cells [60-62,68,142,143] (Table 2). This upregulation is related to T-cell exhaustion; for example, PD-1/PD-L1 ligation triggers T-cell apoptosis by various mechanisms, potentially assisting with viral persistence in the host [64-66].

The expression levels of PD-1, TIM-3, LAG-3, and CTLA-4 on CD4 ${ }^{+}$T-cells from HBV patients are significantly higher than those from healthy controls [64-67]. These levels are closely associated with a loss of cytokine production ability by $\mathrm{CD} 4^{+} \mathrm{T}$-cells; this loss exacerbates $\mathrm{CD} 8^{+} \mathrm{T}$-cell exhaustion, progressing $\mathrm{HBV}$ infection into the chronic phase. As a result of $\mathrm{CD} 4^{+} \mathrm{T}$-cell dysfunction, $\mathrm{CD} 8{ }^{+} \mathrm{T}$-cells, particularly intrahepatic T-cells, exhibit progressive and gradual exhaustion during persistent viral infection, accompanied by persistent high viral loads and high antigen levels [143,144]. Similarly, in chronic HCV infection, the expression of PD-1, TIGIT, TIM-3 and CTLA-4 are also upregulated on CD8 ${ }^{+} \mathrm{T}$-cells $[69-72,145]$ and $\mathrm{CD} 4^{+} \mathrm{T}$-cell $[73,146]$. It is associated with $\mathrm{CD} 8^{+} \mathrm{T}$-cell exhaustion, $\mathrm{CD} 4^{+}$ T-cell dysfunction and chronic low-level inflammation, which results in HCC development [145]. 
Treg cells play an important role in suppressing T-cell activation [147] and releasing regulatory cytokines such as IL-10, TGF- $\beta$, and IL-35 [148]. In the immune clearance and immune tolerance phases of HBV infection, the proliferation of Treg cells is promoted [149]. Levels of PD-1, CTLA-4, and TIM-3 expression are enhanced in Treg cells during HBV infection, and these proteins contribute to the regulatory functions of Treg cells [149-152].

PD-1 plays a critical role in T-cell exhaustion, especially in the persistent infection of hepatitis virus [153]. However, it was reported that T-cell exhaustion also occurred in PD-1 or PD-L1 knockout mice during chronic viral infection, accompanied by the upregulation of other immune checkpoint receptors [154]. These findings suggest that T-cell exhaustion is maintained by various immune checkpoints $[68,143,155]$. In isolated HBV-specific T-cells from a woodchuck model of HBV infection, blocking these immune checkpoints restored exhausted T-cells such that they to responded appropriately to stimulation by HBV antigens $[63,156]$.

Importantly, treatment with an ICI must be monitored for adverse events, such as autoimmune events or increased liver inflammation. A recent study found that TIGIT blockade or deficiency in hepatitis B surface antigen (HBsAg) transgenic mice could promote the development of HCC by reversing the adaptive immune tolerance of hepatic $\mathrm{CD}^{+} \mathrm{T}$-cells to HBsAg [60].

\subsection{Immune Checkpoints Affect Chronic Hepatitis Virus Infection through Cytokine Regulation}

Multiple studies with different models have shown that cytokines play a critical role in the control of HBV replication and chronic infection [157]. IFN-based therapy is the major treatment for chronic hepatitis B (CHB) [157-160]. Proinflammatory cytokines released by Th1 cells, such as IL-12, IL-2, IFN- $\gamma$, and TNF- $\alpha$, can limit acute HBV infection and mediating non-cytolytic viral clearance via different signaling pathways [157]. In contrast, some cytokines like IL-10 and TGF- $\beta$ contribute to impaired immune responses in chronic hepatitis [161,162].

During chronic hepatitis virus infection, immune checkpoints control T-cell cytokine production through various pathways (Table 3). The secretion of Th1 cytokines increases in the acute phase of hepatitis virus infection, then decreases rapidly with disease progression because of viral-specific T-cell dysfunction [163-166]. In contrast, Th2 cytokines, such as IL-4 and IL-10, are less affected, while increases in TGF- $\beta$ and IL-35 levels can downregulate Th1 responses and decrease T-cell function [147,167-169]. Cytokine secretion varies among subsets of Th 2 and Treg cells. Notably, a Th2 bias in the Th1/Th2 cytokine balance is not conducive to a successful antiviral immune response [73,170-174].

An immune checkpoint blockade or genetic knockdown can restore the production of proinflammatory cytokines (Table 3). Accumulating evidence shows that immune checkpoint blockades targeting PD-L1, LAG-3, CTLA-4, or TIM-3 improve the production of Th1 cytokines during HBV infection $[63,175,176]$. Although the detailed mechanism responsible for this effect is currently unclear, CTLA-4 and PD-1 were found to induce the differentiation of $\mathrm{CD} 4^{+}$Th cells toward Th2 cells and increase Th2 cytokine levels during HBV infection [73]. Additionally, PD-1 expression levels are significantly increased in HBV-specific CD4 ${ }^{+}$T-cells, lending support to the idea that immune checkpoints cause cytokine downregulation [143]. Because of its effect on restoring T-cell activity and enhancing cytokine production, immune checkpoint blockade holds promise as a useful antiviral immunotherapy; however, such therapy has the potential to induce the abnormal secretion of many cytokines and chemokines, known as a cytokine storm, or to trigger autoimmune diseases. Clinical trials are underway to study the efficacy of immunotherapy against infection with HBV or HCV (Table 4). 
Table 4. Cytokine secretion altered by immune checkpoints in chronic virus infection.

\begin{tabular}{|c|c|c|c|c|c|}
\hline $\begin{array}{l}\text { Chronic } \\
\text { Virus }\end{array}$ & $\begin{array}{r}\text { Cytokines Sec } \\
\text { Viral In }\end{array}$ & $\begin{array}{l}\text { tion during } \\
\text { ction }\end{array}$ & $\begin{array}{l}\text { Associated } \\
\text { Immune } \\
\text { Checkpoint }\end{array}$ & Effects & Ref. \\
\hline \multirow{7}{*}{ HBV } & \multirow{4}{*}{$\mathrm{TH}-1 / \mathrm{CD} 8^{+} \mathrm{T}$} & IFN- $\gamma \downarrow$ & $\begin{array}{l}\text { CTLA-4, PD-1, } \\
\text { Tim-3, LAG-3, } \\
\text { BTLA }\end{array}$ & $\begin{array}{l}\text { Activate multiple immune responses } \\
\text { Enhance Th1 responses Inhibit cccDNA } \\
\text { replication and accumulation }\end{array}$ & $\begin{array}{c}{[62-64,68,100,143,} \\
151,152,166]\end{array}$ \\
\hline & & IL-2 $\downarrow$ & $\begin{array}{l}\text { CTLA-4, BTLA, } \\
\text { PD-1, Tim-3, } \\
\text { LAG-3 }\end{array}$ & $\begin{array}{l}\text { Induce differentiation and effector function } \\
\text { of T-cell, NK and LAK }\end{array}$ & {$[62,64,67,143]$} \\
\hline & & TNF- $\alpha \downarrow$ & $\begin{array}{l}\text { PD-1, Tim-3, } \\
\text { LAG-3 }\end{array}$ & $\begin{array}{l}\text { Lead to direct clearance of } \\
\text { virus-infection cells }\end{array}$ & {$[64,152,166]$} \\
\hline & & IL-12 $\downarrow$ & PD-1 & Impair host defense and viral clearance & [176] \\
\hline & Treg & $\begin{array}{l}\text { IL-10, } \\
\text { TGF- } \beta \uparrow\end{array}$ & $\begin{array}{l}\text { CTLA-4, PD-1, } \\
\text { Tim-3 }\end{array}$ & $\begin{array}{l}\text { suppress effector T-cells and regulate } \\
\text { liver fibrosis }\end{array}$ & [171-173] \\
\hline & TH-2 & $\begin{array}{l}\text { IL-4, IL-5, } \\
\text { IL-10 }\end{array}$ & LAG-3, PD-1 & $\begin{array}{l}\text { Downregulate the activation of B- and } \\
\text { T-cell proliferation } \\
\text { Suppress TH1 response }\end{array}$ & [64] \\
\hline & TH-17 & $\mathrm{IL}-17 \uparrow$ & TIM-3 & $\begin{array}{l}\text { Promote the exacerbation of liver } \\
\text { inflammation and sustain the } \\
\text { proinflammatory response }\end{array}$ & [167] \\
\hline \multirow{7}{*}{$\mathrm{HCV}$} & \multirow{4}{*}{$\begin{array}{l}\text { TH-1/CD8 }{ }^{+} \\
\text {T-cell }\end{array}$} & IFN- $\gamma \downarrow$ & $\begin{array}{l}\text { LAG-3, PD-1, } \\
\text { Tim-3 }\end{array}$ & $\begin{array}{l}\text { Promote Th1 immune response, suppress } \\
\text { Th2 and Th17 responses }\end{array}$ & {$[71,164]$} \\
\hline & & IL-2 $\downarrow$ & PD-1, CTLA-4 & $\begin{array}{l}\text { Inactivate multiple immune-cell subsets, } \\
\text { including T-cells, NK cells, B-cells, } \\
\text { monocytes, macrophages, and neutrophils }\end{array}$ & [145] \\
\hline & & TNF- $\alpha \downarrow$ & LAG-3 & $\begin{array}{l}\text { Decrease the direct clearance of } \\
\text { virus-infection cells }\end{array}$ & [164] \\
\hline & & IL-12 $\downarrow$ & Tim-3 & $\begin{array}{c}\text { Decrease the stimulation of TH1 responses } \\
\text { that are essential for host defense and } \\
\text { pathogen clearance }\end{array}$ & [173] \\
\hline & Treg & $\begin{array}{c}\text { IL-10, } \\
\text { TGF- } \beta \uparrow\end{array}$ & $\begin{array}{l}\text { PD-1, Tim-3, } \\
\text { CTLA-4 }\end{array}$ & $\begin{array}{l}\text { Limit the secretion of proinflammatory } \\
\text { cytokines and suppress effector T-cells }\end{array}$ & {$[73,146,168]$} \\
\hline & TH-2 & $\begin{array}{l}\text { IL-4, IL-5, } \\
\text { IL-10 }\end{array}$ & PD-1 & $\begin{array}{l}\text { Promote the activation of B and T-cell } \\
\text { proliferation and limit the secretion of } \\
\text { proinflammatory cytokines }\end{array}$ & [169] \\
\hline & TH-17 & $\mathrm{IL}-17 \uparrow$ & Tim-3 & $\begin{array}{l}\text { Promote the exacerbation of liver } \\
\text { inflammation and injury }\end{array}$ & {$[173,174]$} \\
\hline
\end{tabular}

\section{Immune Checkpoints in Influenza}

Recent studies have revealed that immune checkpoints are also involved in influenza virus infection (Table 2). The expression of PD-L1 in human primary airway epithelial cells and the plasma level of Gal-9 were found to drastically increase in $24 \mathrm{~h}$ post-infection with influenza A virus (IAV) [74,75]. Furthermore, a PD-L1 blockade or knockout of Gal-9 in airway epithelial cells enhanced T-cell function and influenza virus clearance [74,76].

T-cell immunity is important for the clearance of respiratory viruses and control of the associated infection. However, T-cell effector functions are impaired in IAV infection because of the highly inflamed airway microenvironment. The expression levels of PD-1, TIM-3, LAG-3, and 2B4 on lung $\mathrm{CD} 8{ }^{+} \mathrm{T}$-cells during a primary influenza virus infection were significantly elevated, and these levels were even higher than the corresponding levels in individuals re-infected with this virus [77]. PD-1 ablation or blockade during IAV infection effectively increased IFN production and preserved CD8 ${ }^{+}$ T-cell effector function, consequently decreasing viral titers [78,79]. Similarly, a significant elevation in TIM-3 expression was found in IAV-infected individuals. TIM-3/Gal-9 interaction was found to limit immune responses to influenza virus. Specifically, Gal-9 knockout mice were able to control IAV infection more successfully compared with wildtype mice, as supported by better virus-specific CD8 ${ }^{+}$T-cell responses and IAV-specific humoral responses [76]. Furthermore, enhanced CTLA-4 
expression on $\mathrm{CD} 8^{+} \mathrm{T}$-cells causes a downregulation of T-cell activation and is significantly associated with influenza encephalopathy [80].

Most influenza virus infections are self-limited because of the rapid clearance of virus. However, excessive immune responses to influenza virus can lead cytokine storms, which cause pathological damage to tissues. Immune checkpoints can limit such immune pathology; for example, TIGIT can reduce immune-mediated tissue damage in an IL-10-dependent manner during acute virus infection [81]. The negative regulatory function of T-cells was found to be improved in a mutant mouse with a deletion in the distal cytoplasmic domain of TIM-3. Furthermore, TIM-3 was reported to reduce pneumonitis in the setting of influenza infection by suppressing excessive T-cell activity [82].

In summary, immune checkpoints have been reported to play two opposing roles in influenza. Immune checkpoints can interfere with the clearance of influenza virus, but they can also limit the inflammatory immune response caused by influenza virus infection. Therefore, when using ICIs to treat acute influenza infection, the patients receiving this therapy must be closely monitored to avoid triggering an elevated lung inflammatory response. Two clinical studies regarding the safety of inactivated influenza vaccines in patients undergoing immunotherapy with ICIs have been completed (Table 4). The results show ICI immunotherapy did not increase the incidence or severity of immune responses to inactivated influenza virus. However, the response to active influenza virus in patients receiving ICI immunotherapy is still not clear.

\section{Immune Checkpoints in COVID-19}

SARS-CoV-2 is an emerging coronavirus that was identified as the causative pathogen for the respiratory illness COVID-19, which was first detected at the end of 2019. Inflammation-mediated damage is the main consequence of SARS-CoV-2 infection. Most severe COVID-19 cases exhibit a cytokine storm syndrome, leading to a poor prognosis [177]. Although the immune response during COVID-19 progression has been extensively studied in the short time since SARS-CoV-2 was identified [178-180], the role of immune checkpoints in this process is still not clear [181]. Reports indicate that the absolute numbers of peripheral blood NK cells, B-cells, and CD4 ${ }^{+}$and CD8 ${ }^{+} \mathrm{T}$ lymphocytes were all lower in patients with acute respiratory distress syndrome due to SARS-CoV-2 infection compared with those in healthy controls. Although fewer in number, these cells were hyperactivated, accompanied with an increase in serum levels of the proinflammatory cytokines IL-6, IL-10, and TNF- $\alpha$ [83,182]. Lymphopenia and the levels of IL-6, IL-10, and TNF- $\alpha$ were found to be negatively associated with COVID-19 patient survival [83,84]. PD-1 expression levels on NK cells and T-cells were found to be highly upregulated in COVID-19 patients [83,85,183]. Specially, an analysis on peripheral blood mononuclear cells from 14 patients in deteriorated condition from COVID-19 and 3 healthy controls revealed that COVID-19 patients have higher levels of both PD-1 and TIM-3 as well as remarkably elevated serum levels of IL-6, IL-10, and TNF- $\alpha$. These findings suggest that immune checkpoint-mediated T-cell exhaustion is involved in the severe symptoms of COVID-19 [83].

Because immune checkpoints appear to be involved in the immune tolerance of SARS-CoV-2 infection, altering viral susceptibility through ICI therapy is theoretically possible. ICIs can usually restore the effector function of the $\mathrm{CD} 8^{+} \mathrm{T}$-cells involved in defense against viral infections. However, the overlap between ICI mechanisms and COVID-19 pathogenesis raises concerns that ICI therapy may potentiate acute respiratory distress syndrome. Cancer immunotherapy as a risk factor has been examined in COVID-19 patients. When death was used as the examination endpoint, treatment with a PD-1 blockade was found not to be associated with an increased risk of COVID-19 severity in patients with cancer $[184,185]$. However, another ICI therapy study conducted on more patients used patient oxygen need as the examination endpoint and found that the disease severity in COVID-19 patients with cancer was associated with the ICI therapy; the authors concluded that ICI treatment was a predictor for hospitalization and severe outcomes [186]. In addition, autoimmune pneumonitis was observed in non-small cell lung cancer patients who were treated with ICI in up to $20 \%$ of cases [187]. Although ICIs are potentially beneficial immunomodulators of $\mathrm{CD} 8^{+} \mathrm{T}$-cell-mediated immune surveillance, they 
can lead to different outcomes depending on the timing of this intervention [85]. Presently, the available data with which to clearly address the use of ICIs in patients with SARS-CoV-2 infection, with or without concurrent cancer, remain very limited.

\section{Immune Checkpoints in Other Viruses}

In addition to their functions in HIV, hepatitis virus, influenza virus, and SARS-CoV-2 infections, the roles of immune checkpoints in infections with other viruses are also being widely studied. The Epstein-Barr virus (EBV), initially described in 1964, was the first identified human tumor virus [188]; infection with this virus is linked to the development of lymphoma, nasopharyngeal carcinoma, and many types of malignancies. EBV can latently infect memory B-cells [189]. The expression levels of PD-1 and CTLA-4 are upregulated on EBV-infected T-cells, and PD-L1 is expressed on EBV-infected lymphoma cells $[90,91]$. A blockade of PD-1 and CTLA-4 enhanced T-cell responses and prolonged the survival time of EBV-infected humanized mice. However, another study found that PD- $1^{+} \mathrm{CD} 8^{+} \mathrm{T}$-cells from EBV-infected mice with reconstituted human immune system components (huNSG mice) still retained proliferative capacity and that these animals had a worse outcome following treatment with anti-PD-1 antibodies [92]. The huNSG mice are NSG immunodeficient mice with HLA-A2 transgene and intrahepatically engraftment of $\mathrm{HLA}-\mathrm{A} 2^{+} \mathrm{CD} 34^{+}$hematopoietic progenitor cells purified from human fetal liver tissue, which possess peripheral blood reconstitution of human $\mathrm{CD} 45^{+} \mathrm{CD} 19^{+} \mathrm{B}$, $\mathrm{CD}^{+} \mathrm{T}$, and NKp46 $6^{+} \mathrm{NK}$ cells, as well as $\mathrm{CD}^{+}$and $\mathrm{CD} 8^{+} \mathrm{T}$-cells. The expression levels of TIM-3, LAG-3, BTLA-4, and 2B4 were found to be upregulated in EBV-specific T-cells and associated with high virus load. The upregulation of immune checkpoint receptors by T-cells indicates that these cells are dysfunctional, and a combination of T-cell dysfunction and PD-L1 overexpression contributes to the immune escape of both active and latent EBV [93].

Like EBV and HIV, herpes simplex virus (HSV) can cause a latent infection. HSV latent infection occurs in the trigeminal ganglion [190]. When HSV reactivates from latency, it can trigger more serious complications, such as herpes stromal keratitis (HSK) [191]. Related studies show that both $\mathrm{CD}^{+}{ }^{+} \mathrm{T}$-cells and $\mathrm{CD} 88^{+} \mathrm{T}$-cells in draining lymph nodes have increased expression levels of PD-1, TIM-3, and LAG-3 after HSV infection [86,87]. This upregulated PD-1 and LAG3 expression led to the exhaustion of tissue-resident $\mathrm{CD}^{+} \mathrm{T}$-cells and the loss of antiviral response to symptomatic reactivation, whereas a blockade of LAG-3 and PD-1 improved the function of HSV-specific CD8 ${ }^{+}$ T-cells and significantly reduced the reactivation of latent HSV virus in a rabbit model $[88,89]$.

Ebola virus is a single-stranded RNA virus belonging to the filovirus family. Infection with Ebola virus causes an acute, highly lethal hemorrhagic fever in humans. An analysis of the differences in T-cell activation status between fatalities and survivors of Ebola virus infection uncovered that CTLA-4 overexpression was correlated with high viremia [94].

\section{Summary and Outlook}

The immune responses to viral infection vary among viruses. In general, immune checkpointmediated immune suppression, an important mechanism for virus immune escape, is widely observed in viral infections. The upregulation of immune checkpoint proteins represents a critical point in the balance between an effective T-cell response and T-cell exhaustion. Shifting this balance through treatment with ICIs should restore T-cell competence and promote virus clearance. Thus, ICIs could be useful in the treatment of viral infections.

During some acute viral infections, such as those due to influenza virus or SARS-CoV-2, PD-1, and other immune checkpoint proteins are upregulated quickly to assist with viral immune escape and to counter the severe inflammatory response triggered by infection. Studies have recently uncovered roles played by immune checkpoints in chronic viral infections, like those due to HIV or HBV. The establishment of latent viral infection might largely rely on immune checkpoint-mediated immune suppression. Because viral infection, unlike most cancers, is usually accompanied by a strong inflammatory response, treating viral infections with ICIs poses a risk not present in their 
application to usual cancer treatment: restoring T-cell function might exacerbate the inflammatory response caused by the viral infection. Several questions remain regarding the application of such immunotherapy to viral infections. It will be important to determine: (1) which stage of infection is most appropriate for conducting an intervention with ICI immunotherapy; (2) how to accurately determine or predict the clinical responsiveness or adverse events from immune checkpoint blockade therapy; and (3) how to improve and control the clinical response rates of immune checkpoint blockade treatment. Therefore, further study and real-world observations are needed to confirm the potential utility of ICIs for antiviral therapy.

Author Contributions: Q.Z., Z.H., and H.C. conceived the review. H.C., Q.Z., and G.L. wrote the manuscript. J.Z., K.Z., H.X., C.L., X.S., Y.L., C.X., and H.W. improve the manuscript. Z.H., H.C., and Q.Z. revised the manuscript. All authors have read and agreed to the published version of the manuscript.

Funding: This research was funded by the National Key R\&D Program of China (No. 2017YFA053900), the National Natural Science Foundation of China (No. 31670360, 81973293 and U1702286), the Science and Technology Program of Guangdong Province (2017B030301016 and 2018A030313252), the Foundation Committee of basic and applied basic research of Guangdong Province (2019B1515120029), the Medical Scientific Research Foundation of Guangdong Province (A2018257), the Shenzhen Science and Technology Project (JCYJ20170818095732006, JCYJ20190808122605563 and JCYJ20170818092448118), and the SZU Top Ranking Project (86000000210).

Conflicts of Interest: The authors declare no conflict of interest.

\section{References}

1. Schweitzer, A.; Horn, J.; Mikolajczyk, R.T.; Krause, G.; Ott, J.J. Estimations of worldwide prevalence of chronic hepatitis B virus infection: A systematic review of data published between 1965 and 2013. Lancet (Lond. Engl.) 2015, 386, 1546-1555. [CrossRef]

2. DALYs, G.B.D.; Collaborators, H. Global, regional, and national disability-adjusted life-years (DALYs) for 333 diseases and injuries and healthy life expectancy (HALE) for 195 countries and territories, 1990-2016: A systematic analysis for the Global Burden of Disease Study 2016. Lancet (Lond. Engl.) 2017, 390, 1260-1344.

3. Angelosanto, J.M.; Blackburn, S.D.; Crawford, A.; Wherry, E.J. Progressive loss of memory T cell potential and commitment to exhaustion during chronic viral infection. J. Virol. 2012, 86, 8161-8170. [CrossRef] [PubMed]

4. Hashimoto, M.; Kamphorst, A.O.; Im, S.J.; Kissick, H.T.; Pillai, R.N.; Ramalingam, S.S.; Araki, K.; Ahmed, R. CD8 T Cell Exhaustion in Chronic Infection and Cancer: Opportunities for Interventions. Ann. Rev. Med. 2018, 69, 301-318. [CrossRef] [PubMed]

5. Alegre, M.L.; Frauwirth, K.A.; Thompson, C.B. T-cell regulation by CD28 and CTLA-4. Nat. Rev. Immunol. 2001, 1, 220-228. [CrossRef]

6. Chen, L. Co-inhibitory molecules of the B7-CD28 family in the control of T-cell immunity. Nat. Rev. Immunol. 2004, 4, 336-347. [CrossRef]

7. Waterhouse, P.; Penninger, J.M.; Timms, E.; Wakeham, A.; Shahinian, A.; Lee, K.P.; Thompson, C.B.; Griesser, H.; Mak, T.W. Lymphoproliferative disorders with early lethality in mice deficient in Ctla-4. Science 1995, 270, 985-988. [CrossRef]

8. Korman, A.J.; Peggs, K.S.; Allison, J.P. Checkpoint blockade in cancer immunotherapy. Adv. Immunol. 2006, 90, 297-339.

9. Krummel, M.F.; Allison, J.P. CD28 and CTLA-4 have opposing effects on the response of T cells to stimulation. J. Exp. Med. 1995, 182, 459-465. [CrossRef]

10. Leach, D.R.; Krummel, M.F.; Allison, J.P. Enhancement of antitumor immunity by CTLA-4 blockade. Science 1996, 271, 1734-1736. [CrossRef]

11. Ishida, Y.; Agata, Y.; Shibahara, K.; Honjo, T. Induced expression of PD-1, a novel member of the immunoglobulin gene superfamily, upon programmed cell death. EMBO J. 1992, 11, 3887-3895. [CrossRef] [PubMed]

12. Tang, R.; Rangachari, M.; Kuchroo, V.K. Tim-3: A co-receptor with diverse roles in T cell exhaustion and tolerance. Semin. Immunol. 2019, 42, 101302. [CrossRef] [PubMed]

13. Andrews, L.P.; Marciscano, A.E.; Drake, C.G.; Vignali, D.A.A. LAG3 (CD223) as a cancer immunotherapy target. Immunol. Rev. 2017, 276, 80-96. [CrossRef] 
14. Cohn, L.B.; Chomont, N.; Deeks, S.G. The Biology of the HIV-1 Latent Reservoir and Implications for Cure Strategies. Cell Host Microbe 2020, 27, 519-530. [CrossRef] [PubMed]

15. Kasamon, Y.L.; de Claro, R.A.; Wang, Y.; Shen, Y.L.; Farrell, A.T.; Pazdur, R. FDA Approval Summary: Nivolumab for the Treatment of Relapsed or Progressive Classical Hodgkin Lymphoma. Oncologist 2017, 22, 585-591. [CrossRef]

16. Robert, C.; Thomas, L.; Bondarenko, I.; O’Day, S.; Weber, J.; Garbe, C.; Lebbe, C.; Baurain, J.-F.; Testori, A.; Grob, J.-J.; et al. Ipilimumab plus dacarbazine for previously untreated metastatic melanoma. N. Engl. J. Med. 2011, 364, 2517-2526. [CrossRef]

17. Popovic, A.; Jaffee, E.M.; Zaidi, N. Emerging strategies for combination checkpoint modulators in cancer immunotherapy. J. Clin. Investig. 2018, 128, 3209-3218. [CrossRef]

18. Agata, Y.; Kawasaki, A.; Nishimura, H.; Ishida, Y.; Tsubata, T.; Yagita, H.; Honjo, T. Expression of the PD-1 antigen on the surface of stimulated mouse $\mathrm{T}$ and B lymphocytes. Int. Immunol. 1996, 8, 765-772. [CrossRef]

19. Thibult, M.-L.; Mamessier, E.; Gertner-Dardenne, J.; Pastor, S.; Just-Landi, S.; Xerri, L.; Chetaille, B.; Olive, D. PD-1 is a novel regulator of human B-cell activation. Int. Immunol. 2013, 25, 129-137. [CrossRef]

20. Yokosuka, T.; Takamatsu, M.; Kobayashi-Imanishi, W.; Hashimoto-Tane, A.; Azuma, M.; Saito, T. Programmed cell death 1 forms negative costimulatory microclusters that directly inhibit $\mathrm{T}$ cell receptor signaling by recruiting phosphatase SHP2. J. Exp. Med. 2012, 209, 1201-1217. [CrossRef]

21. Sheppard, K.-A.; Fitz, L.J.; Lee, J.M.; Benander, C.; George, J.A.; Wooters, J.; Qiu, Y.; Jussif, J.M.; Carter, L.L.; Wood, C.R.; et al. PD-1 inhibits T-cell receptor induced phosphorylation of the ZAP70/CD3zeta signalosome and downstream signaling to PKCtheta. FEBS Lett. 2004, 574, 37-41. [CrossRef] [PubMed]

22. Chemnitz, J.M.; Parry, R.V.; Nichols, K.E.; June, C.H.; Riley, J.L. SHP-1 and SHP-2 associate with immunoreceptor tyrosine-based switch motif of programmed death 1 upon primary human $\mathrm{T}$ cell stimulation, but only receptor ligation prevents T cell activation. J. Immunol. 2004, 173, 945-954. [CrossRef] [PubMed]

23. Rota, G.; Niogret, C.; Dang, A.T.; Barros, C.R.; Fonta, N.P.; Alfei, F.; Morgado, L.; Zehn, D.; Birchmeier, W.; Vivier, E.; et al. Shp-2 Is Dispensable for Establishing T Cell Exhaustion and for PD-1 Signaling In Vivo. Cell Rep. 2018, 23, 39-49. [CrossRef] [PubMed]

24. Hosseini, A.; Gharibi, T.; Marofi, F.; Babaloo, Z.; Baradaran, B. CTLA-4: From mechanism to autoimmune therapy. Int. Immunopharmacol. 2020, 80, 106221. [CrossRef]

25. Qureshi, O.S.; Kaur, S.; Hou, T.Z.; Jeffery, L.E.; Poulter, N.S.; Briggs, Z.; Kenefeck, R.; Willox, A.K.; Royle, S.J.; Rappoport, J.Z.; et al. Constitutive clathrin-mediated endocytosis of CTLA-4 persists during T cell activation. J. Biol. Chem. 2012, 287, 9429-9440. [CrossRef]

26. Chambers, C.A.; Kuhns, M.S.; Egen, J.G.; Allison, J.P. CTLA-4-mediated inhibition in regulation of T cell responses: Mechanisms and manipulation in tumor immunotherapy. Annu. Rev. Immunol. 2001, 19, 565-594. [CrossRef]

27. Chuang, E.; Fisher, T.S.; Morgan, R.W.; Robbins, M.D.; Duerr, J.M.; Vander Heiden, M.G.; Gardner, J.P.; Hambor, J.E.; Neveu, M.J.; Thompson, C.B. The CD28 and CTLA-4 receptors associate with the serine/threonine phosphatase PP2A. Immunity 2000, 13, 313-322. [CrossRef]

28. Fraser, J.H.; Rincón, M.; McCoy, K.D.; Le Gros, G. CTLA4 ligation attenuates AP-1, NFAT and NF-kappaB activity in activated T cells. Eur. J. Immunol. 1999, 29, 838-844. [CrossRef]

29. Olsson, C.; Riesbeck, K.; Dohlsten, M.; Michaëlsson, E.; Riebeck, K. CTLA-4 ligation suppresses CD28-induced NF-kappaB and AP-1 activity in mouse T cell blasts. J. Biol. Chem. 1999, 274, 14400-14405. [CrossRef]

30. Schurich, A.; Khanna, P.; Lopes, A.R.; Han, K.J.; Peppa, D.; Micco, L.; Nebbia, G.; Kennedy, P.T.F.; Geretti, A.-M.; Dusheiko, G.; et al. Role of the coinhibitory receptor cytotoxic T lymphocyte antigen-4 on apoptosis-Prone CD8 T cells in persistent hepatitis B virus infection. Hepatology 2011, 53, 1494-1503. [CrossRef]

31. Liu, S.; Zhang, H.; Li, M.; Hu, D.; Li, C.; Ge, B.; Jin, B.; Fan, Z. Recruitment of Grb2 and SHIP1 by the ITT-like motif of TIGIT suppresses granule polarization and cytotoxicity of NK cells. Cell Death Diff. 2013, 20, 456-464. [CrossRef] [PubMed]

32. Rangachari, M.; Zhu, C.; Sakuishi, K.; Xiao, S.; Karman, J.; Chen, A.; Angin, M.; Wakeham, A.; Greenfield, E.A.; Sobel, R.A.; et al. Bat3 promotes T cell responses and autoimmunity by repressing Tim-3-mediated cell death and exhaustion. Nat. Med. 2012, 18, 1394-1400. [CrossRef] [PubMed]

33. Tomkowicz, B.; Walsh, E.; Cotty, A.; Verona, R.; Sabins, N.; Kaplan, F.; Santulli-Marotto, S.; Chin, C.-N.; Mooney, J.; Lingham, R.B.; et al. TIM-3 Suppresses Anti-CD3/CD28-Induced TCR Activation and IL-2 Expression through the NFAT Signaling Pathway. PLoS ONE 2015, 10, e0140694. [CrossRef] [PubMed] 
34. Lee, M.J.; Woo, M.-Y.; Chwae, Y.-J.; Kwon, M.-H.; Kim, K.; Park, S. Down-regulation of interleukin-2 production by CD4(+) T cells expressing TIM-3 through suppression of NFAT dephosphorylation and AP-1 transcription. Immunobiology 2012, 217, 986-995. [CrossRef]

35. Joller, N.; Hafler, J.P.; Brynedal, B.; Kassam, N.; Spoerl, S.; Levin, S.D.; Sharpe, A.H.; Kuchroo, V.K. Cutting edge: TIGIT has T cell-intrinsic inhibitory functions. J. Immunol. 2011, 186, 1338-1342. [CrossRef]

36. Yu, X.; Harden, K.; Gonzalez, L.C.; Francesco, M.; Chiang, E.; Irving, B.; Tom, I.; Ivelja, S.; Refino, C.J.; Clark, H.; et al. The surface protein TIGIT suppresses T cell activation by promoting the generation of mature immunoregulatory dendritic cells. Nat. Immunol. 2009, 10, 48-57. [CrossRef]

37. Joller, N.; Lozano, E.; Burkett, P.R.; Patel, B.; Xiao, S.; Zhu, C.; Xia, J.; Tan, T.G.; Sefik, E.; Yajnik, V.; et al. Treg cells expressing the coinhibitory molecule TIGIT selectively inhibit proinflammatory Th1 and Th17 cell responses. Immunity 2014, 40, 569-581. [CrossRef]

38. Maeda, T.K.; Sugiura, D.; Okazaki, I.-M.; Maruhashi, T.; Okazaki, T. Atypical motifs in the cytoplasmic region of the inhibitory immune co-receptor LAG-3 inhibit T cell activation. J. Biol. Chem. 2019, 294, 6017-6026. [CrossRef]

39. Cai, G.; Freeman, G.J. The CD160, BTLA, LIGHT/HVEM pathway: A bidirectional switch regulating T-cell activation. Immunol. Rev. 2009, 229, 244-258. [CrossRef]

40. Xu, X.; Hou, B.; Fulzele, A.; Masubuchi, T.; Zhao, Y.; Wu, Z.; Hu, Y.; Jiang, Y.; Ma, Y.; Wang, H.; et al. PD-1 and BTLA regulate $\mathrm{T}$ cell signaling differentially and only partially through SHP1 and SHP2. J. Cell Biol. 2020, 219, 6. [CrossRef]

41. Gavrieli, M.; Murphy, K.M. Association of Grb-2 and PI3K p85 with phosphotyrosile peptides derived from BTLA. Biochem. Biophys. Res. Commun. 2006, 345, 1440-1445. [CrossRef] [PubMed]

42. Day, C.L.; Kaufmann, D.E.; Kiepiela, P.; Brown, J.A.; Moodley, E.S.; Reddy, S.; Mackey, E.W.; Miller, J.D.; Leslie, A.J.; DePierres, C.; et al. PD-1 expression on HIV-specific T cells is associated with T-cell exhaustion and disease progression. Nature 2006, 443, 350-354. [CrossRef] [PubMed]

43. Banga, R.; Procopio, F.A.; Noto, A.; Pollakis, G.; Cavassini, M.; Ohmiti, K.; Corpataux, J.M.; de Leval, L.; Pantaleo, G.; Perreau, M. PD-1(+) and follicular helper T cells are responsible for persistent HIV-1 transcription in treated aviremic individuals. Nat. Med. 2016, 22, 754-761. [CrossRef] [PubMed]

44. Wherry, E.J. T cell exhaustion. Nat. Immunol. 2011, 12, 492-499. [CrossRef] [PubMed]

45. Pardons, M.; Baxter, A.E.; Massanella, M.; Pagliuzza, A.; Fromentin, R.; Dufour, C.; Leyre, L.; Routy, J.P.; Kaufmann, D.E.; Chomont, N. Single-cell characterization and quantification of translation-competent viral reservoirs in treated and untreated HIV infection. PLoS Pathog. 2019, 15, e1007619. [CrossRef]

46. Tian, X.; Zhang, A.; Qiu, C.; Wang, W.; Yang, Y.; Qiu, C.; Liu, A.; Zhu, L.; Yuan, S.; Hu, H.; et al. The upregulation of LAG-3 on T cells defines a subpopulation with functional exhaustion and correlates with disease progression in HIV-infected subjects. J. Immunol. 2015, 194, 3873-3882. [CrossRef]

47. Noto, A.; Procopio, F.A.; Banga, R.; Suffiotti, M.; Corpataux, J.M.; Cavassini, M.; Riva, A.; Fenwick, C.; Gottardo, R.; Perreau, M.; et al. CD32 and PD-1 Lymph Node CD4 T Cells Support Persistent HIV-1 Transcription in Treated Aviremic Individuals. J. Virol. 2018, 92, 20. [CrossRef]

48. Riley, J.L.; Schlienger, K.; Blair, P.J.; Carreno, B.; Craighead, N.; Kim, D.; Carroll, R.G.; June, C.H. Modulation of susceptibility to HIV-1 infection by the cytotoxic T lymphocyte antigen 4 costimulatory molecule. J. Exp. Med. 2000, 191, 1987-1997. [CrossRef]

49. Hatano, H.; Jain, V.; Hunt, P.W.; Lee, T.H.; Sinclair, E.; Do, T.D.; Hoh, R.; Martin, J.N.; McCune, J.M.; Hecht, F.; et al. Cell-based measures of viral persistence are associated with immune activation and programmed cell death protein 1 (PD-1)-expressing CD4+ T cells. J. Infect. Dis. 2013, 208, 50-56. [CrossRef]

50. Leng, Q.; Bentwich, Z.; Magen, E.; Kalinkovich, A.; Borkow, G. CTLA-4 upregulation during HIV infection: Association with anergy and possible target for therapeutic intervention. AIDS (Lond. Engl.) 2002, 16, 519-529. [CrossRef]

51. Kaufmann, D.E.; Kavanagh, D.G.; Pereyra, F.; Zaunders, J.J.; Mackey, E.W.; Miura, T.; Palmer, S.; Brockman, M.; Rathod, A.; Piechocka-Trocha, A.; et al. Upregulation of CTLA-4 by HIV-specific CD4+ T cells correlates with disease progression and defines a reversible immune dysfunction. Nat. Immunol. 2007, 8, 1246-1254. [CrossRef] [PubMed]

52. Kaufmann, D.E.; Walker, B.D. PD-1 and CTLA-4 inhibitory cosignaling pathways in HIV infection and the potential for therapeutic intervention. J. Immunol. 2009, 182, 5891-5897. [CrossRef] [PubMed] 
53. Jones, R.B.; Ndhlovu, L.C.; Barbour, J.D.; Sheth, P.M.; Jha, A.R.; Long, B.R.; Wong, J.C.; Satkunarajah, M.; Schweneker, M.; Chapman, J.M.; et al. Tim-3 expression defines a novel population of dysfunctional T cells with highly elevated frequencies in progressive HIV-1 infection. J. Exp. Med. 2008, 205, 2763-2779. [CrossRef]

54. Trautmann, L.; Janbazian, L.; Chomont, N.; Said, E.A.; Gimmig, S.; Bessette, B.; Boulassel, M.R.; Delwart, E.; Sepulveda, H.; Balderas, R.S.; et al. Upregulation of PD-1 expression on HIV-specific CD8+ T cells leads to reversible immune dysfunction. Nat. Med. 2006, 12, 1198-1202. [CrossRef]

55. Chew, G.M.; Fujita, T.; Webb, G.M.; Burwitz, B.J.; Wu, H.L.; Reed, J.S.; Hammond, K.B.; Clayton, K.L.; Ishii, N.; Abdel-Mohsen, M.; et al. TIGIT Marks Exhausted T Cells, Correlates with Disease Progression, and Serves as a Target for Immune Restoration in HIV and SIV Infection. PLoS Pathog. 2016, 12, e1005349. [CrossRef] [PubMed]

56. Cao, Q.H.; Xue, Y.L.; Wang, Y. [Association of PD-1 expression on CD4+ CD25 nt/hi CD127 lo regulatory T cells with disease progression in HIV-1 infected patients]. Xi Bao Yu Fen Zi Mian Yi Xue Za Zhi Chin. J. Cell. Mol. Immunol. 2009, 25, 1020-1022.

57. Khaitan, A.; Kravietz, A.; Mwamzuka, M.; Marshed, F.; Ilmet, T.; Said, S.; Ahmed, A.; Borkowsky, W.; Unutmaz, D. FOXP3+Helios+ Regulatory T Cells, Immune Activation, and Advancing Disease in HIV-Infected Children. J. Acquir. Immune Defic. Syndr. (1999) 2016, 72, 474-484. [CrossRef]

58. Huang, C.T.; Workman, C.J.; Flies, D.; Pan, X.; Marson, A.L.; Zhou, G.; Hipkiss, E.L.; Ravi, S.; Kowalski, J.; Levitsky, H.I.; et al. Role of LAG-3 in regulatory T cells. Immunity 2004, 21, 503-513. [CrossRef]

59. Koch, K.; Koch, N.; Sandaradura de Silva, U.; Jung, N.; Schulze zur Wiesch, J.; Fätkenheuer, G.; Hartmann, P.; Romerio, F.; Lehmann, C. Increased Frequency of CD49b/LAG-3(+) Type 1 Regulatory T Cells in HIV-Infected Individuals. AIDS Res. Hum. Retrovir. 2015, 31, 1238-1246. [CrossRef]

60. Zong, L.; Peng, H.; Sun, C.; Li, F.; Zheng, M.; Chen, Y.; Wei, H.; Sun, R.; Tian, Z. Breakdown of adaptive immunotolerance induces hepatocellular carcinoma in HBsAg-tg mice. Nat. Commun. 2019, 10, 221. [CrossRef]

61. Li, F.J.; Zhang, Y.; Jin, G.X.; Yao, L.; Wu, D.Q. Expression of LAG-3 is coincident with the impaired effector function of HBV-specific CD8(+) T cell in HCC patients. Immunol. Lett. 2013, 150, 116-122. [CrossRef] [PubMed]

62. Li, H.; Wu, K.; Tao, K.; Chen, L.; Zheng, Q.; Lu, X.; Liu, J.; Shi, L.; Liu, C.; Wang, G.; et al. Tim-3/galectin-9 signaling pathway mediates T-cell dysfunction and predicts poor prognosis in patients with hepatitis B virus-associated hepatocellular carcinoma. Hepatology 2012, 56, 1342-1351. [CrossRef] [PubMed]

63. Wu, W.; Shi, Y.; Li, S.; Zhang, Y.; Liu, Y.; Wu, Y.; Chen, Z. Blockade of Tim-3 signaling restores the virus-specific $\mathrm{CD}^{+}$T-cell response in patients with chronic hepatitis B. Eur. J. Immunol. 2012, 42, 1180-1191. [CrossRef]

64. Dong, Y.; Li, X.; Zhang, L.; Zhu, Q.; Chen, C.; Bao, J.; Chen, Y. CD4 T cell exhaustion revealed by high PD-1 and LAG-3 expression and the loss of helper T cell function in chronic hepatitis B. BMC Immunol. 2019, 20, 27. [CrossRef] [PubMed]

65. Nebbia, G.; Peppa, D.; Schurich, A.; Khanna, P.; Singh, H.D.; Cheng, Y.; Rosenberg, W.; Dusheiko, G.; Gilson, R.; ChinAleong, J.; et al. Upregulation of the Tim-3/galectin-9 pathway of T cell exhaustion in chronic hepatitis B virus infection. PLoS ONE 2012, 7, e47648. [CrossRef]

66. Wang, L.; Zhao, C.; Peng, Q.; Shi, J.; Gu, G. Expression levels of CD28, CTLA-4, PD-1 and Tim-3 as novel indicators of T-cell immune function in patients with chronic hepatitis B virus infection. Biomed. Rep. 2014, 2, 270-274. [CrossRef] [PubMed]

67. Yu, Y.; Wu, H.; Tang, Z.; Zang, G. CTLA4 silencing with siRNA promotes deviation of Th1/Th2 in chronic hepatitis B patients. Cell. Mol. Immunol. 2009, 6, 123-127. [CrossRef]

68. Ye, B.; Li, X.; Dong, Y.; Wang, Y.; Tian, L.; Lin, S.; Liu, X.; Kong, H.; Chen, Y. Increasing LAG-3 expression suppresses T-cell function in chronic hepatitis B: A balance between immunity strength and liver injury extent. Medicine 2017, 96, e5275. [CrossRef]

69. Nakamoto, N.; Kaplan, D.E.; Coleclough, J.; Li, Y.; Valiga, M.E.; Kaminski, M.; Shaked, A.; Olthoff, K.; Gostick, E.; Price, D.A.; et al. Functional restoration of HCV-specific CD8 T cells by PD-1 blockade is defined by PD-1 expression and compartmentalization. Gastroenterology 2008, 134, 1927-1937.e1-2. [CrossRef]

70. Ackermann, C.; Smits, M.; Woost, R.; Eberhard, J.M.; Peine, S.; Kummer, S.; Marget, M.; Kuntzen, T.; Kwok, W.W.; Lohse, A.W.; et al. HCV-specific CD4+ T cells of patients with acute and chronic HCV infection display high expression of TIGIT and other co-inhibitory molecules. Sci. Rep. 2019, 9, 10624. [CrossRef] 
71. Golden-Mason, L.; Palmer, B.E.; Kassam, N.; Townshend-Bulson, L.; Livingston, S.; McMahon, B.J.; Castelblanco, N.; Kuchroo, V.; Gretch, D.R.; Rosen, H.R. Negative immune regulator Tim-3 is overexpressed on $\mathrm{T}$ cells in hepatitis $\mathrm{C}$ virus infection and its blockade rescues dysfunctional CD4+ and CD8+ T cells. J. Virol. 2009, 83, 9122-9130. [CrossRef] [PubMed]

72. Salem, M.L.; El-Badawy, A. Programmed death-1/programmed death-L1 signaling pathway and its blockade in hepatitis C virus immunotherapy. World J. Hepatol. 2015, 7, 2449-2458. [CrossRef] [PubMed]

73. Fernandez-Ponce, C.; Dominguez-Villar, M.; Aguado, E.; Garcia-Cozar, F. CD4+ primary T cells expressing HCV-core protein upregulate Foxp3 and IL-10, suppressing CD4 and CD8 T cells. PLoS ONE 2014, 9, e85191. [CrossRef] [PubMed]

74. McNally, B.; Ye, F.; Willette, M.; Flaño, E. Local blockade of epithelial PDL-1 in the airways enhances T cell function and viral clearance during influenza virus infection. J. Virol. 2013, 87, 12916-12924. [CrossRef]

75. Katoh, S.; Ikeda, M.; Shimizu, H.; Mouri, K.; Obase, Y.; Kobashi, Y.; Fukushima, K.; Hirashima, M.; Oka, M. Increased Levels of Plasma Galectin-9 in Patients with Influenza Virus Infection. Tohoku J. Exp. Med. 2014, 232, 263-267. [CrossRef]

76. Sharma, S.; Sundararajan, A.; Suryawanshi, A.; Kumar, N.; Veiga-Parga, T.; Kuchroo, V.K.; Thomas, P.G.; Sangster, M.Y.; Rouse, B.T. T cell immunoglobulin and mucin protein-3 (Tim-3)/Galectin-9 interaction regulates influenza A virus-specific humoral and CD8 T-cell responses. Proc. Natl. Acad. Sci. USA 2011, 108, 19001-19006. [CrossRef]

77. Erickson, J.J.; Rogers, M.C.; Hastings, A.K.; Tollefson, S.J.; Williams, J.V. Programmed death-1 impairs secondary effector lung $\mathrm{CD}^{+} \mathrm{T}$ cells during respiratory virus reinfection. J. Immunol. 2014, 193, 5108-5117. [CrossRef]

78. Erickson, J.J.; Gilchuk, P.; Hastings, A.K.; Tollefson, S.J.; Johnson, M.; Downing, M.B.; Boyd, K.L.; Johnson, J.E.; Kim, A.S.; Joyce, S.; et al. Viral acute lower respiratory infections impair CD8+ T cells through PD-1. J. Clin. Investig. 2012, 122, 2967-2982. [CrossRef]

79. Rutigliano, J.A.; Sharma, S.; Morris, M.Y.; Oguin, T.H.; McClaren, J.L.; Doherty, P.C.; Thomas, P.G. Highly pathological influenza A virus infection is associated with augmented expression of PD-1 by functionally compromised virus-specific CD8+ T cells. J. Virol. 2014, 88, 1636-1651. [CrossRef]

80. Ayukawa, H.; Matsubara, T.; Kaneko, M.; Hasegawa, M.; Ichiyama, T.; Furukawa, S. Expression of CTLA-4 (CD152) in peripheral blood T cells of children with influenza virus infection including encephalopathy in comparison with respiratory syncytial virus infection. Clin. Exp. Immunol. 2004, 137, 151-155. [CrossRef]

81. Schorer, M.; Rakebrandt, N.; Lambert, K.; Hunziker, A.; Pallmer, K.; Oxenius, A.; Kipar, A.; Stertz, S.; Joller, N. TIGIT limits immune pathology during viral infections. Nat. Commun. 2020, 11, 1288. [CrossRef] [PubMed]

82. Cho, J.L.; Roche, M.I.; Sandall, B.; Brass, A.L.; Seed, B.; Xavier, R.J.; Medoff, B.D. Enhanced Tim3 activity improves survival after influenza infection. J. Immunol. 2012, 189, 2879-2889. [CrossRef] [PubMed]

83. Diao, B.; Wang, C.; Tan, Y.; Chen, X.; Liu, Y.; Ning, L.; Chen, L.; Li, M.; Liu, Y.; Wang, G.; et al. Reduction and Functional Exhaustion of T Cells in Patients With Coronavirus Disease 2019 (COVID-19). Front. Immunol. 2020, 11, 827. [CrossRef] [PubMed]

84. Zhou, F.; Yu, T.; Du, R.; Fan, G.; Liu, Y.; Liu, Z.; Xiang, J.; Wang, Y.; Song, B.; Gu, X.; et al. Clinical course and risk factors for mortality of adult inpatients with COVID-19 in Wuhan, China: A retrospective cohort study. Lancet 2020, 395, 1054-1062. [CrossRef]

85. Chiappelli, F.; Khakshooy, A.; Greenberg, G. CoViD-19 Immunopathology and Immunotherapy. Bioinformation 2020, 16, 219-222. [CrossRef] [PubMed]

86. Allen, S.J.; Mott, K.R.; Zandian, M.; Ghiasi, H. Immunization with different viral antigens alters the pattern of $\mathrm{T}$ cell exhaustion and latency in herpes simplex virus type 1-infected mice. J. Virol. 2010, 84, 12315-12324. [CrossRef]

87. Mott, K.R.; Bresee, C.J.; Allen, S.J.; BenMohamed, L.; Wechsler, S.L.; Ghiasi, H. Level of herpes simplex virus type 1 latency correlates with severity of corneal scarring and exhaustion of CD8+ T cells in trigeminal ganglia of latently infected mice. J. Virol. 2009, 83, 2246-2254. [CrossRef]

88. Roy, S.; Coulon, P.G.; Prakash, S.; Srivastava, R.; Geertsema, R.; Dhanushkodi, N.; Lam, C.; Nguyen, V.; Gorospe, E.; Nguyen, A.M.; et al. Blockade of PD-1 and LAG-3 Immune Checkpoints Combined with Vaccination Restores the Function of Antiviral Tissue-Resident CD8 T Cells and Reduces Ocular Herpes Simplex Infection and Disease in HLA Transgenic Rabbits. J. Virol. 2019, 93, 18. [CrossRef] 
89. Srivastava, R.; Dervillez, X.; Khan, A.A.; Chentoufi, A.A.; Chilukuri, S.; Shukr, N.; Fazli, Y.; Ong, N.N.; Afifi, R.E.; Osorio, N.; et al. The Herpes Simplex Virus Latency-Associated Transcript Gene Is Associated with a Broader Repertoire of Virus-Specific Exhausted CD8+ T Cells Retained within the Trigeminal Ganglia of Latently Infected HLA Transgenic Rabbits. J. Virol. 2016, 90, 3913-3928. [CrossRef]

90. Larsen, M.; Sauce, D.; Deback, C.; Arnaud, L.; Mathian, A.; Miyara, M.; Boutolleau, D.; Parizot, C.; Dorgham, K.; Papagno, L.; et al. Exhausted cytotoxic control of Epstein-Barr virus in human lupus. PLoS Pathog. 2011, 7, e1002328. [CrossRef]

91. Ma, S.D.; Xu, X.; Jones, R.; Delecluse, H.J.; Zumwalde, N.A.; Sharma, A.; Gumperz, J.E.; Kenney, S.C. PD-1/CTLA-4 Blockade Inhibits Epstein-Barr Virus-Induced Lymphoma Growth in a Cord Blood Humanized-Mouse Model. PLoS Pathog. 2016, 12, e1005642. [CrossRef] [PubMed]

92. Chatterjee, B.; Deng, Y.; Holler, A.; Nunez, N.; Azzi, T.; Vanoaica, L.D.; Müller, A.; Zdimerova, H.; Antsiferova, O.; Zbinden, A.; et al. CD8+ T cells retain protective functions despite sustained inhibitory receptor expression during Epstein-Barr virus infection in vivo. PLoS Pathog. 2019, 15, e1007748. [CrossRef] [PubMed]

93. Bi, X.-W.; Wang, H.; Zhang, W.-W.; Wang, J.-H.; Liu, W.-J.; Xia, Z.-J.; Huang, H.-Q.; Jiang, W.-Q.; Zhang, Y.-J.; Wang, L. PD-L1 is upregulated by EBV-driven LMP1 through NF-kB pathway and correlates with poor prognosis in natural killer/T-cell lymphoma. J. Hematol. Oncol. 2016, 9, 109. [CrossRef] [PubMed]

94. Ruibal, P.; Oestereich, L.; Lüdtke, A.; Becker-Ziaja, B.; Wozniak, D.M.; Kerber, R.; Korva, M.; Cabeza-Cabrerizo, M.; Bore, J.A.; Koundouno, F.R.; et al. Unique human immune signature of Ebola virus disease in Guinea. Nature 2016, 533, 100-104. [CrossRef]

95. Sakhdari, A.; Mujib, S.; Vali, B.; Yue, F.Y.; MacParland, S.; Clayton, K.; Jones, R.B.; Liu, J.; Lee, E.Y.; Benko, E.; et al. Tim-3 negatively regulates cytotoxicity in exhausted CD8+ T cells in HIV infection. PLoS ONE 2012, 7, e40146. [CrossRef]

96. Seung, E.; Dudek, T.E.; Allen, T.M.; Freeman, G.J.; Luster, A.D.; Tager, A.M. PD-1 blockade in chronically HIV-1-infected humanized mice suppresses viral loads. PLoS ONE 2013, 8, e77780. [CrossRef]

97. Grabmeier-Pfistershammer, K.; Stecher, C.; Zettl, M.; Rosskopf, S.; Rieger, A.; Zlabinger, G.J.; Steinberger, P. Antibodies targeting BTLA or TIM-3 enhance HIV-1 specific T cell responses in combination with PD-1 blockade. Clin. Immunol. 2017, 183, 167-173. [CrossRef]

98. Rallón, N.; García, M.; García-Samaniego, J.; Cabello, A.; Álvarez, B.; Restrepo, C.; Nistal, S.; Górgolas, M.; Benito, J.M. Expression of PD-1 and Tim-3 markers of T-cell exhaustion is associated with CD4 dynamics during the course of untreated and treated HIV infection. PLoS ONE 2018, 13, e0193829. [CrossRef]

99. de Kivit, S.; Lempsink, L.J.; Plants, J.; Martinson, J.; Keshavarzian, A.; Landay, A.L. Modulation of TIM-3 expression on NK and T cell subsets in HIV immunological non-responders. Clin. Immunol. 2015, 156, 28-35. [CrossRef]

100. Morou, A.; Palmer, B.E.; Kaufmann, D.E. Distinctive features of CD4+ T cell dysfunction in chronic viral infections. Curr. Opin. HIV AIDS 2014, 9, 446-451. [CrossRef]

101. Fromentin, R.; Bakeman, W.; Lawani, M.B.; Khoury, G.; Hartogensis, W.; DaFonseca, S.; Killian, M.; Epling, L.; Hoh, R.; Sinclair, E.; et al. CD4+ T Cells Expressing PD-1, TIGIT and LAG-3 Contribute to HIV Persistence during ART. PLoS Pathog. 2016, 12, e1005761. [CrossRef] [PubMed]

102. Llewellyn, G.N.; Seclén, E.; Wietgrefe, S.; Liu, S.; Chateau, M.; Pei, H.; Perkey, K.; Marsden, M.D.; Hinkley, S.J.; Paschon, D.E.; et al. Humanized Mouse Model of HIV-1 Latency with Enrichment of Latent Virus in PD-1 and TIGIT CD4 T Cells. J. Virol. 2019, 93, 10. [CrossRef] [PubMed]

103. Campbell, C.; Rudensky, A. Roles of Regulatory T Cells in Tissue Pathophysiology and Metabolism. Cell Metab. 2020, 31, 18-25. [CrossRef] [PubMed]

104. Ciurkiewicz, M.; Herder, V.; Beineke, A. Beneficial and Detrimental Effects of Regulatory T Cells in Neurotropic Virus Infections. Int. J. Mol. Sci. 2020, 21, 1705. [CrossRef] [PubMed]

105. Rowe, J.H.; Ertelt, J.M.; Way, S.S. Foxp3(+) regulatory T cells, immune stimulation and host defence against infection. Immunology 2012, 136, 1-10. [CrossRef]

106. Elahi, S.; Niki, T.; Hirashima, M.; Horton, H. Galectin-9 binding to Tim-3 renders activated human CD4+ T cells less susceptible to HIV-1 infection. Blood 2012, 119, 4192-4204. [CrossRef]

107. Jain, N.; Nguyen, H.; Chambers, C.; Kang, J. Dual function of CTLA-4 in regulatory T cells and conventional T cells to prevent multiorgan autoimmunity. Proc. Natl. Acad. Sci. USA 2010, 107, 1524-1528. [CrossRef] 
108. Nikolova, M.; Wiedemann, A.; Muhtarova, M.; Achkova, D.; Lacabaratz, C.; Lévy, Y. Subset- and Antigen-Specific Effects of Treg on CD8+ T Cell Responses in Chronic HIV Infection. PLoS Pathog. 2016, 12, e1005995. [CrossRef]

109. Jones, R.B.; Walker, B.D. HIV-specific CD8 ${ }^{+}$T cells and HIV eradication. J. Clin. Investig. 2016, 126, 455-463. [CrossRef]

110. Dyck, L.; Mills, K.H.G. Immune checkpoints and their inhibition in cancer and infectious diseases. Eur. J. Immunol. 2017, 47, 765-779. [CrossRef]

111. Freeman, M.L.; Shive, C.L.; Nguyen, T.P.; Younes, S.-A.; Panigrahi, S.; Lederman, M.M. Cytokines and T-Cell Homeostasis in HIV Infection. J. Infect. Dis. 2016, 214 (Suppl. 2), S51-S57. [CrossRef] [PubMed]

112. Akhmetzyanova, I.; Drabczyk, M.; Neff, C.P.; Gibbert, K.; Dietze, K.K.; Werner, T.; Liu, J.; Chen, L.; Lang, K.S.; Palmer, B.E.; et al. PD-L1 Expression on Retrovirus-Infected Cells Mediates Immune Escape from CD8+ T Cell Killing. PLoS Pathog. 2015, 11, e1005224.

113. Meyaard, L.; Miedema, F. Immune dysregulation and CD4+ T cell loss in HIV-1 infection. Springer Semin. Immunopathol. 1997, 18, 285-303. [CrossRef] [PubMed]

114. Doitsh, G.; Galloway, N.L.K.; Geng, X.; Yang, Z.; Monroe, K.M.; Zepeda, O.; Hunt, P.W.; Hatano, H.; Sowinski, S.; Muñoz-Arias, I.; et al. Cell death by pyroptosis drives CD4 T-cell depletion in HIV-1 infection. Nature 2014, 505, 509-514. [CrossRef] [PubMed]

115. Cummins, N.W.; Badley, A.D. Making sense of how HIV kills infected CD4 T cells: Implications for HIV cure. Mol. Cell Ther. 2014, 2, 20. [CrossRef] [PubMed]

116. Doitsh, G.; Greene, W.C. Dissecting How CD4 T Cells Are Lost During HIV Infection. Cell Host Microbe 2016, 19, 280-291. [CrossRef]

117. Lee, G.Q.; Lichterfeld, M. Diversity of HIV-1 reservoirs in CD4+ T-cell subpopulations. Curr. Opin. HIV AIDS 2016, 11, 383-387. [CrossRef]

118. Pierson, T.; McArthur, J.; Siliciano, R.F. Reservoirs for HIV-1: Mechanisms for viral persistence in the presence of antiviral immune responses and antiretroviral therapy. Annu. Rev. Immunol. 2000, 18, 665-708. [CrossRef]

119. Kwon, K.J.; Timmons, A.E.; Sengupta, S.; Simonetti, F.R.; Zhang, H.; Hoh, R.; Deeks, S.G.; Siliciano, J.D.; Siliciano, R.F. Different human resting memory CD4 T cell subsets show similar low inducibility of latent HIV-1 proviruses. Sci. Transl. Med. 2020, 12, 528. [CrossRef]

120. Martínez-Bonet, M.; Puertas, M.C.; Fortuny, C.; Ouchi, D.; Mellado, M.J.; Rojo, P.; Noguera-Julian, A.; Muñoz-Fernández, M.A.; Martinez-Picado, J. Establishment and Replenishment of the Viral Reservoir in Perinatally HIV-1-infected Children Initiating Very Early Antiretroviral Therapy. Clin. Infect. Dis. 2015, 61, 1169-1178. [CrossRef]

121. Strongin, Z.; Sharaf, R.; VanBelzen, D.J.; Jacobson, J.M.; Connick, E.; Volberding, P.; Skiest, D.J.; Gandhi, R.T.; Kuritzkes, D.R.; O'Doherty, U.; et al. Effect of Short-Term Antiretroviral Therapy Interruption on Levels of Integrated HIV DNA. J. Virol. 2018, 92, 12. [CrossRef] [PubMed]

122. Horiike, M.; Iwami, S.; Kodama, M.; Sato, A.; Watanabe, Y.; Yasui, M.; Ishida, Y.; Kobayashi, T.; Miura, T.; Igarashi, T. Lymph nodes harbor viral reservoirs that cause rebound of plasma viremia in SIV-infected macaques upon cessation of combined antiretroviral therapy. Virology 2012, 423, 107-118. [CrossRef] [PubMed]

123. Murray, J.M.; Zaunders, J.J.; McBride, K.L.; Xu, Y.; Bailey, M.; Suzuki, K.; Cooper, D.A.; Emery, S.; Kelleher, A.D.; Koelsch, K.K. HIV DNA subspecies persist in both activated and resting memory CD4+ T cells during antiretroviral therapy. J. Virol. 2014, 88, 3516-3526. [CrossRef] [PubMed]

124. Mohan, T.; Bhatnagar, S.; Gupta, D.L.; Rao, D.N. Current understanding of HIV-1 and T-cell adaptive immunity: Progress to date. Microb. Pathog. 2014, 73, 60-69. [CrossRef]

125. D'Souza, M.; Fontenot, A.P.; Mack, D.G.; Lozupone, C.; Dillon, S.; Meditz, A.; Wilson, C.C.; Connick, E.; Palmer, B.E. Programmed death 1 expression on HIV-specific CD4+ T cells is driven by viral replication and associated with T cell dysfunction. J. Immunol. 2007, 179, 1979-1987. [CrossRef]

126. Evans, V.A.; van der Sluis, R.M.; Solomon, A.; Dantanarayana, A.; McNeil, C.; Garsia, R.; Palmer, S.; Fromentin, R.; Chomont, N.; Sékaly, R.P.; et al. Programmed cell death-1 contributes to the establishment and maintenance of HIV-1 latency. AIDS (Lond. Engl.) 2018, 32, 1491-1497. [CrossRef]

127. Okazaki, T.; Maeda, A.; Nishimura, H.; Kurosaki, T.; Honjo, T. PD-1 immunoreceptor inhibits B cell receptor-mediated signaling by recruiting src homology 2-domain-containing tyrosine phosphatase 2 to phosphotyrosine. Proc. Natl. Acad. Sci. USA 2001, 98, 13866-13871. [CrossRef] 
128. Perreau, M.; Savoye, A.L.; De Crignis, E.; Corpataux, J.M.; Cubas, R.; Haddad, E.K.; De Leval, L.; Graziosi, C.; Pantaleo, G. Follicular helper T cells serve as the major CD4 T cell compartment for HIV-1 infection, replication, and production. J. Exp. Med. 2013, 210, 143-156. [CrossRef]

129. Garcia-Bates, T.M.; Palma, M.L.; Shen, C.; Gambotto, A.; Macatangay, B.J.C.; Ferris, R.L.; Rinaldo, C.R.; Mailliard, R.B. Contrasting Roles of the PD-1 Signaling Pathway in Dendritic Cell-Mediated Induction and Regulation of HIV-1-Specific Effector T Cell Functions. J. Virol. 2019, 93, 5. [CrossRef]

130. McGary, C.S.; Deleage, C.; Harper, J.; Micci, L.; Ribeiro, S.P.; Paganini, S.; Kuri-Cervantes, L.; Benne, C.; Ryan, E.S.; Balderas, R.; et al. CTLA-4(+)PD-1(-) Memory CD4(+) T Cells Critically Contribute to Viral Persistence in Antiretroviral Therapy-Suppressed, SIV-Infected Rhesus Macaques. Immunity 2017, 47, 776-788.e5. [CrossRef]

131. El-Far, M.; Ancuta, P.; Routy, J.-P.; Zhang, Y.; Bakeman, W.; Bordi, R.; DaFonseca, S.; Said, E.A.; Gosselin, A.; Tep, T.-S.; et al. Nef promotes evasion of human immunodeficiency virus type 1-infected cells from the CTLA-4-mediated inhibition of T-cell activation. J. Gen. Virol. 2015, 96 Pt 6, 1463-1477. [CrossRef]

132. Porichis, F.; Kwon, D.S.; Zupkosky, J.; Tighe, D.P.; McMullen, A.; Brockman, M.A.; Pavlik, D.F.; Rodriguez-Garcia, M.; Pereyra, F.; Freeman, G.J.; et al. Responsiveness of HIV-specific CD4 T cells to PD-1 blockade. Blood 2011, 118, 965-974. [CrossRef] [PubMed]

133. Freeman, G.J.; Wherry, E.J.; Ahmed, R.; Sharpe, A.H. Reinvigorating exhausted HIV-specific T cells via PD-1-PD-1 ligand blockade. J. Exp. Med. 2006, 203, 2223-2227. [CrossRef] [PubMed]

134. Fromentin, R.; DaFonseca, S.; Costiniuk, C.T.; El-Far, M.; Procopio, F.A.; Hecht, F.M.; Hoh, R.; Deeks, S.G.; Hazuda, D.J.; Lewin, S.R.; et al. PD-1 blockade potentiates HIV latency reversal ex vivo in CD4(+) T cells from ART-suppressed individuals. Nat. Commun. 2019, 10, 814. [CrossRef] [PubMed]

135. Peeridogaheh, H.; Meshkat, Z.; Habibzadeh, S.; Arzanlou, M.; Shahi, J.M.; Rostami, S.; Gerayli, S.; Teimourpour, R. Current concepts on immunopathogenesis of hepatitis B virus infection. Virus Res. 2018, 245, 29-43. [CrossRef] [PubMed]

136. El-Serag, H.B. Epidemiology of viral hepatitis and hepatocellular carcinoma. Gastroenterology 2012, 142, 1264-1273.e1. [CrossRef]

137. Piekarska, A.; Jabłonowska, E.; Garlicki, A.; Sitko, M.; Mazur, W.; Jaroszewicz, J.; Czauz-Andrzejuk, A.; Buczyńska, I.; Simon, K.; Lorenc, B.; et al. Real life results of direct acting antiviral therapy for HCV infection in HIV-HCV-coinfected patients: Epi-Ter2 study. AIDS Care 2019, 32, 762-769. [CrossRef]

138. Allweiss, L.; Dandri, M. The Role of cccDNA in HBV Maintenance. Viruses 2017, 9, 156. [CrossRef]

139. Chen, D.S. Toward elimination and eradication of hepatitis B. J. Gastroenterol. Hepatol. 2010, $25,19-25$. [CrossRef]

140. Mohd-Ismail, N.K.; Lim, Z.; Gunaratne, J.; Tan, Y.-J. Mapping the Interactions of HBV cccDNA with Host Factors. Int. J. Mol. Sci. 2019, 20, 4276. [CrossRef]

141. Zhang, Z.; Zhang, J.Y.; Wherry, E.J.; Jin, B.; Xu, B.; Zou, Z.S.; Zhang, S.Y.; Li, B.S.; Wang, H.F.; Wu, H.; et al. Dynamic programmed death 1 expression by virus-specific CD8 $\mathrm{T}$ cells correlates with the outcome of acute hepatitis B. Gastroenterology 2008, 134, 1938-1949.e1-3. [CrossRef] [PubMed]

142. Yong, Y.K.; Saeidi, A.; Tan, H.Y.; Rosmawati, M.; Enström, P.F.; Batran, R.A.; Vasuki, V.; Chattopadhyay, I.; Murugesan, A.; Vignesh, R.; et al. Hyper-Expression of PD-1 Is Associated with the Levels of Exhausted and Dysfunctional Phenotypes of Circulating CD161TCR iV $\alpha 7.2$ Mucosal-Associated Invariant T Cells in Chronic Hepatitis B Virus Infection. Front. Immunol. 2018, 9, 472. [CrossRef] [PubMed]

143. Cai, G.; Nie, X.; Li, L.; Hu, L.; Wu, B.; Lin, J.; Jiang, C.; Wang, H.; Wang, X.; Shen, Q. B and T lymphocyte attenuator is highly expressed on intrahepatic T cells during chronic HBV infection and regulates their function. J. Gastroenterol. 2013, 48, 1362-1372. [CrossRef] [PubMed]

144. Wieland, D.; Hofmann, M.; Thimme, R. Overcoming CD8+ T-Cell Exhaustion in Viral Hepatitis: Lessons from the Mouse Model and Clinical Perspectives. Dig. Dis. 2017, 35, 334-338. [CrossRef] [PubMed]

145. Golden-Mason, L.; Palmer, B.; Klarquist, J.; Mengshol, J.A.; Castelblanco, N.; Rosen, H.R. Upregulation of PD-1 expression on circulating and intrahepatic hepatitis $\mathrm{C}$ virus-specific CD8+ T cells associated with reversible immune dysfunction. J. Virol. 2007, 81, 9249-9258. [CrossRef] [PubMed]

146. Raziorrouh, B.; Ulsenheimer, A.; Schraut, W.; Heeg, M.; Kurktschiev, P.; Zachoval, R.; Jung, M.; Thimme, R.; Neumann-Haefelin, C.; Horster, S.; et al. Inhibitory molecules that regulate expansion and restoration of HCV-specific CD4+ T cells in patients with chronic infection. (1528-0012 (Electronic)). Gastroenterol 2011, 141, 1422-1431.e6. [CrossRef] 
147. Tavakolpour, S.; Alavian, S.M.; Sali, S. Manipulation of Regulatory Cells' Responses to Treatments for Chronic Hepatitis B Virus Infection. Hepat. Mon. 2016, 16, e37927. [CrossRef]

148. Trehanpati, N.; Vyas, A.K. Immune Regulation by T Regulatory Cells in Hepatitis B Virus-Related Inflammation and Cancer. Scand. J. Immunol. 2017, 85, 175-181. [CrossRef]

149. Hu, C.C.; Jeng, W.J.; Chen, Y.C.; Fang, J.H.; Huang, C.H.; Teng, W.; Hsieh, Y.C.; Lin, Y.C.; Chien, R.N.; Sheen, I.S.; et al. Memory Regulatory T cells Increase Only In Inflammatory Phase of Chronic Hepatitis B Infection and Related to Galectin-9/Tim-3 interaction. Sci. Rep. 2017, 7, 15280. [CrossRef]

150. Feng, C.; Cao, L.J.; Song, H.F.; Xu, P.; Chen, H.; Xu, J.C.; Zhu, X.Y.; Zhang, X.G.; Wang, X.F. Expression of PD-L1 on CD4+CD25+Foxp3+ Regulatory T Cells of Patients with Chronic HBV Infection and Its Correlation with Clinical Parameters. Viral Immunol. 2015, 28, 418-424. [CrossRef]

151. Cao, H.; Zhang, R.; Zhang, W. CTLA-4 interferes with the HBV-specific T cell immune response (Review). Int. J. Mol. Med. 2018, 42, 703-712. [CrossRef] [PubMed]

152. Dinney, C.M.; Zhao, L.D.; Conrad, C.D.; Duker, J.M.; Karas, R.O.; Hu, Z.; Hamilton, M.A.; Gillis, T.R.; Parker, T.M.; Fan, B.; et al. Regulation of HBV-specific CD8(+) T cell-mediated inflammation is diversified in different clinical presentations of HBV infection. J. Microbiol. 2015, 53, 718-724. [CrossRef] [PubMed]

153. Kroy, D.C.; Ciuffreda, D.; Cooperrider, J.H.; Tomlinson, M.; Hauck, G.D.; Aneja, J.; Berger, C.; Wolski, D.; Carrington, M.; Wherry, E.J.; et al. Liver environment and HCV replication affect human T-cell phenotype and expression of inhibitory receptors. Gastroenterology 2014, 146, 550-561. [CrossRef] [PubMed]

154. Nassal, M. HBV cccDNA: Viral persistence reservoir and key obstacle for a cure of chronic hepatitis B. Gut 2015, 64, 1972-1984. [CrossRef]

155. Wang, Q.; Pan, W.; Liu, Y.; Luo, J.; Zhu, D.; Lu, Y.; Feng, X.; Yang, X.; Dittmer, U.; Lu, M.; et al. Hepatitis B Virus-Specific CD8+ T Cells Maintain Functional Exhaustion after Antigen Reexposure in an Acute Activation Immune Environment. Front. Immunol. 2018, 9, 219. [CrossRef]

156. Balsitis, S.; Gali, V.; Mason, P.J.; Chaniewski, S.; Levine, S.M.; Wichroski, M.J.; Feulner, M.; Song, Y.; Granaldi, K.; Loy, J.K.; et al. Safety and efficacy of anti-PD-L1 therapy in the woodchuck model of HBV infection. PLoS ONE 2018, 13, e0190058. [CrossRef]

157. Xia, Y.; Protzer, U. Control of Hepatitis B Virus by Cytokines. Viruses 2017, 9, 18. [CrossRef]

158. Xia, Y.; Stadler, D.; Lucifora, J.; Reisinger, F.; Webb, D.; Hösel, M.; Michler, T.; Wisskirchen, K.; Cheng, X.; Zhang, K.; et al. Interferon- $\gamma$ and Tumor Necrosis Factor- $\alpha$ Produced by T Cells Reduce the HBV Persistence Form, cccDNA, Without Cytolysis. Gastroenterology 2016, 150, 194-205. [CrossRef]

159. Ouaguia, L.; Morales, O.; Mrizak, D.; Ghazal, K.; Boleslawski, E.; Auriault, C.; Pancré, V.; de Launoit, Y.; Conti, F.; Delhem, N. Overexpression of Regulatory T Cells Type 1 (Tr1) Specific Markers in a Patient with HCV-Induced Hepatocellular Carcinoma. ISRN Hepatol. 2013, 2013, 928485. [CrossRef]

160. Li, X.; Liu, X.; Tian, L.; Chen, Y. Cytokine-Mediated Immunopathogenesis of Hepatitis B Virus Infections. Clin. Rev. Allergy Immunol. 2016, 50, 41-54. [CrossRef]

161. Speletas, M.; Argentou, N.; Germanidis, G.; Vasiliadis, T.; Mantzoukis, K.; Patsiaoura, K.; Nikolaidis, P.; Karanikas, V.; Ritis, K.; Germenis, A.E. Foxp3 expression in liver correlates with the degree but not the cause of inflammation. Med. Inflamm. 2011, 2011, 827565. [CrossRef] [PubMed]

162. Su, Z.J.; Yu, X.P.; Guo, R.Y.; Ming, D.S.; Huang, L.Y.; Su, M.L.; Deng, Y.; Lin, Z.Z. Changes in the balance between Treg and Th17 cells in patients with chronic hepatitis B. Diagn. Microbiol. Infect. Dis. 2013, 76, 437-444. [CrossRef] [PubMed]

163. Lechmann, M.; Woitas, R.P.; Langhans, B.; Kaiser, R.; Ihlenfeldt, H.G.; Jung, G.; Sauerbruch, T.; Spengler, U. Decreased frequency of $\mathrm{HCV}$ core-specific peripheral blood mononuclear cells with type 1 cytokine secretion in chronic hepatitis C. J. Hepatol. 1999, 31, 971-978. [CrossRef]

164. Chen, N.; Liu, Y.; Guo, Y.; Chen, Y.; Liu, X.; Liu, M. Lymphocyte activation gene 3 negatively regulates the function of intrahepatic hepatitis C virus-specific CD8+ T cells. J. Gastroenterol. Hepatol. 2015, 30, 1788-1795. [CrossRef]

165. Maier, H.; Isogawa, M.; Freeman, G.J.; Chisari, F.V. PD-1:PD-L1 interactions contribute to the functional suppression of virus-specific CD8+ T lymphocytes in the liver. J. Immunol. 2007, 178, 2714-2720. [CrossRef]

166. Horiuchi, Y.; Takagi, A.; Kobayashi, N.; Moriya, O.; Nagai, T.; Moriya, K.; Tsutsumi, T.; Koike, K.; Akatsuka, T. Effect of the infectious dose and the presence of hepatitis $C$ virus core gene on mouse intrahepatic CD8 T cells. Hepatol. Res. Off. J. Jpn. Soc. Hepatol. 2014, 44, E240-E252. [CrossRef] 
167. Cooksley, H.; Riva, A.; Katzarov, K.; Hadzhiolova-Lebeau, T.; Pavlova, S.; Simonova, M.; Williams, R.; Chokshi, S. Differential Expression of Immune Inhibitory Checkpoint Signatures on Antiviral and Inflammatory T Cell Populations in Chronic Hepatitis B. J. Interferon Cytokine Res. Off. J. Int. Soc. Interferon Cytokine Res. 2018, 38, 273-282. [CrossRef]

168. Wang, W.; Tong, Z.; Zhong, J.; Zhang, L.; Zhang, H.; Su, Y.; Gao, B.; Zhang, C. Identification of IL-10-secreting CD8CD28PD-1 regulatory T cells associated with chronic hepatitis C virus infection. Immunol. Lett. 2018, 202, 16-22. [CrossRef]

169. Xiao, W.; Jiang, L.F.; Deng, X.Z.; Zhu, D.Y.; Pei, J.P.; Xu, M.L.; Li, B.J.; Wang, C.J.; Zhang, J.H.; Zhang, Q.; et al. PD-1/PD-L1 signal pathway participates in HCV F protein-induced T cell dysfunction in chronic HCV infection. Immunol. Res. 2016, 64, 412-423. [CrossRef]

170. Townsend, E.C.; Zhang, G.Y.; Ali, R.; Firke, M.; Moon, M.S.; Han, M.A.T.; Fram, B.; Glenn, J.S.; Kleiner, D.E.; Koh, C.; et al. The balance of type 1 and type 2 immune responses in the contexts of hepatitis B infection and hepatitis D infection. J. Gastroenterol. Hepatol. 2019, 34, 764-775. [CrossRef]

171. Chen, W.; Jin, W.; Wahl, S.M. Engagement of cytotoxic T lymphocyte-associated antigen 4 (CTLA-4) induces transforming growth factor beta (TGF-beta) production by murine CD4(+) T cells. J. Exp. Med. 1998, 188, 1849-1857. [CrossRef] [PubMed]

172. Ji, X.J.; Ma, C.J.; Wang, J.M.; Wu, X.Y.; Niki, T.; Hirashima, M.; Moorman, J.P.; Yao, Z.Q. HCV-infected hepatocytes drive CD4+ CD25+ Foxp3+ regulatory T-cell development through the Tim-3/Gal-9 pathway. Eur. J. Immunol. 2013, 43, 458-467. [CrossRef] [PubMed]

173. Wang, J.M.; Ma, C.J.; Li, G.Y.; Wu, X.Y.; Thayer, P.; Greer, P.; Smith, A.M.; High, K.P.; Moorman, J.P.; Yao, Z.Q. Tim-3 alters the balance of IL-12/IL-23 and drives TH17 cells: Role in hepatitis B vaccine failure during hepatitis C infection. Vaccine 2013, 31, 2238-2245. [CrossRef] [PubMed]

174. Wang, J.M.; Shi, L.; Ma, C.J.; Ji, X.J.; Ying, R.S.; Wu, X.Y.; Wang, K.S.; Li, G.; Moorman, J.P.; Yao, Z.Q. Differential regulation of interleukin-12 (IL-12)/IL-23 by Tim-3 drives T(H)17 cell development during hepatitis C virus infection. J. Virol. 2013, 87, 4372-4383. [CrossRef]

175. Chigbu, D.I.; Loonawat, R.; Sehgal, M.; Patel, D.; Jain, P. Hepatitis C Virus Infection: Host-Virus Interaction and Mechanisms of Viral Persistence. Cells 2019, 8, 376. [CrossRef]

176. Ma, C.J.; Ni, L.; Zhang, Y.; Zhang, C.L.; Wu, X.Y.; Atia, A.N.; Thayer, P.; Moorman, J.P.; Yao, Z.Q. PD-1 negatively regulates interleukin-12 expression by limiting STAT-1 phosphorylation in monocytes/macrophages during chronic hepatitis C virus infection. Immunology 2011, 132, 421-431. [CrossRef]

177. Mehta, P.; McAuley, D.F.; Brown, M.; Sanchez, E.; Tattersall, R.S.; Manson, J.J. COVID-19: Consider cytokine storm syndromes and immunosuppression. Lancet 2020, 395, 1033-1034. [CrossRef]

178. Chowdhury, M.A.; Hossain, N.; Kashem, M.A.; Shahid, M.A.; Alam, A. Immune response in COVID-19: A review. J. Infect. Public Health 2020. [CrossRef]

179. Citarella, F.; Russano, M.; Pantano, F.; Dell'Aquila, E.; Vincenzi, B.; Tonini, G.; Santini, D. Facing SARS-CoV-2 outbreak in immunotherapy era. Future Oncol. 2020, 16, 1475-1485. [CrossRef]

180. Guihot, A.; Litvinova, E.; Autran, B.; Debré, P.; Vieillard, V. Cell-Mediated Immune Responses to COVID-19 Infection. Front. Immunol. 2020, 11, 1662. [CrossRef]

181. Gambichler, T.; Reuther, J.; Scheel, C.; Becker, J. On the use of immune checkpoint inhibitors in patients with viral infections including COVID-19. J. ImmunoTher. Cancer 2020, 8, e001145. [CrossRef]

182. Huang, C.; Wang, Y.; Li, X.; Ren, L.; Zhao, J.; Hu, Y.; Zhang, L.; Fan, G.; Xu, J.; Gu, X.; et al. Clinical features of patients infected with 2019 novel coronavirus in Wuhan, China. Lancet 2020, 395, 497-506. [CrossRef]

183. Demaria, O.; Carvelli, J.; Batista, L.; Thibult, M.-L.; Morel, A.; André, P.; Morel, Y.; Vély, F.; Vivier, E. Identification of druggable inhibitory immune checkpoints on Natural Killer cells in COVID-19. Cell. Mol. Immunol. 2020, 1-3. [CrossRef]

184. Lee, L.Y.W.; Cazier, J.B.; Starkey, T.; Turnbull, C.D.; Kerr, R.; Middleton, G. COVID-19 mortality in patients with cancer on chemotherapy or other anticancer treatments: A prospective cohort study. Lancet 2020, 395, 1919-1926. [CrossRef]

185. Luo, J.; Rizvi, H.; Egger, J.; Preeshagul, I.; Wolchok, J.; Hellmann, M. Impact of PD-1 Blockade on Severity of COVID-19 in Patients with Lung Cancers. Cancer Discov. 2020, CD-20. [CrossRef] [PubMed]

186. Robilotti, E.; Babady, N.; Mead, P.; Rolling, T.; Perez-Johnston, R.; Bernardes, M.; Bogler, Y.; Caldararo, M.; Figueroa, C.; Glickman, M.; et al. Determinants of COVID-19 disease severity in patients with cancer. Nat. Med. 2020, 26, 1218-1223. [CrossRef] 
187. Suresh, K.; Voong, K.; Shankar, B.; Forde, P.; Ettinger, D.; Marrone, K.; Kelly, R.; Hann, C.; Levy, B.; Feliciano, J.; et al. Pneumonitis in Non-Small Cell Lung Cancer Patients Receiving Immune Checkpoint Immunotherapy: Incidence and Risk Factors. J. Thorac. Oncol. 2018, 13, 1930-1939. [CrossRef]

188. Esau, D. Viral Causes of Lymphoma: The History of Epstein-Barr Virus and Human T-Lymphotropic Virus 1. Virology (Auckl) 2017, 8, 1178122X17731772. [CrossRef]

189. Ressing, M.E.; van Gent, M.; Gram, A.M.; Hooykaas, M.J.G.; Piersma, S.J.; Wiertz, E.J.H.J. Immune Evasion by Epstein-Barr Virus. Curr. Top Microbiol. Immunol. 2015, 391, 355-381.

190. Kennedy, P.G.E.; Rovnak, J.; Badani, H.; Cohrs, R.J. A comparison of herpes simplex virus type 1 and varicella-zoster virus latency and reactivation. J. Gen. Virol. 2015, 96 Pt 7, 1581-1602. [CrossRef]

191. Lobo, A.-M.; Agelidis, A.M.; Shukla, D. Pathogenesis of herpes simplex keratitis: The host cell response and ocular surface sequelae to infection and inflammation. Ocul. Surf. 2019, 17, 40-49. [CrossRef] [PubMed]

C 2020 by the authors. Licensee MDPI, Basel, Switzerland. This article is an open access article distributed under the terms and conditions of the Creative Commons Attribution (CC BY) license (http://creativecommons.org/licenses/by/4.0/). 